\title{
37. RADIOLARIANS FROM LEG 122, EXMOUTH AND WOMBAT PLATEAUS, INDIAN OCEAN1
}

\author{
Charles D. Blome ${ }^{2}$
}

\begin{abstract}
Sites 759 through 764 were drilled during Ocean Drilling Program Leg 122 on the Exmouth and Wombat plateaus off northwest Australia, eastern Indian Ocean. Radiolarian recovery was generally poor due to unsuitable lithofacies. A few Quaternary radiolarian faunas were recovered from most of the sites. Rare and poorly preserved Oligocene and Eocene radiolarian faunas were recovered from Holes 760A, 761B, 761C, and 762B. Poorly preserved Cretaceous radiolarians occur in samples from Holes 761B, 762C, 763B, and 763C. Chert intervals from Cores 122-761B-28X, 122-761C-5R, and 122-761C-6R contain moderately well-preserved Cretaceous radiolarian faunas (upper Albian, mid- to upper Cenomanian, and mid-Albian, respectively). Rare fragments of Upper Triassic radiolarians were recovered from sections in Holes 759B, 760B, and 764A.

The only well-preserved pre-Quaternary radiolarians are in lower and upper Paleocene faunas (Bekoma campechensis Zone) recovered from Site 761, Sections 122-761B-16X-1 to 122-761C-19X-CC. The composition of these faunas differs somewhat from that of isolated coeval Paleocene faunas from Deep Sea Drilling Project sites in the Atlantic, Gulf of Mexico, tropical Pacific, eastern Indian Ocean, and near Spain and North Africa, as well as from several on-land sites in North America, Cuba, and the USSR.
\end{abstract}

\section{INTRODUCTION}

The Exmouth Plateau is part of one of the oldest continental margins in the world. It consists of rifted and deeply subsided continental crust covered by a $10-\mathrm{km}$-thick Phanerozoic sedimentary sequence. Seismic-reflector data compiled prior to Ocean Drilling Program (ODP) Leg 122 (Exon et al., 1982) indicate that the Exmouth Plateau stratigraphy includes Holocene to Miocene pelagic ooze, Eocene chalk, and Upper Cretaceous carbonates and marls (mature ocean depositional environment) overlying middle to Lower Cretaceous (?Upper Jurassic) shallow marine shales (juvenile ocean mud environment). Jurassic coal measures and shelf carbonates (rifting paralic sedimentation) and Middle and Upper Triassic shallow marine and fluviodeltaic sediments (intracratonic environment) were deposited prior to breakup in both the northern and southern parts of the plateau.

The major objectives of Leg 122 were

1. To determine the Late Triassic and Jurassic prerift and synrift history and rift-drift transition in a starved passive continental margin setting;

2. To study the Cretaceous to Cenozoic postbreakup development of sedimentation and paleoenvironment from a juvenile to mature ocean;

3. To study the distribution of Jurassic, Cretaceous, and Tertiary depositional sequences in a relatively undisturbed passive margin setting and test the latest eustatic sea-level curve models (Haq et al., 1987, 1988);

4. To refine the Mesozoic geologic time scale;

5. To investigate the middle Cretaceous anoxic sedimentation in terrigenous, shallow-marine, and deep-marine environments; and

6. To document the Cretaceous/Tertiary boundary event (Haq, von Rad, O'Connell, et al., 1990, pp. 12-13).

\footnotetext{
${ }^{1}$ von Rad, U., Haq, B. U., et al., 1992. Proc. ODP, Sci. Results, 122: College Station, TX (Ocean Drilling Program).

2 U.S. Geological Survey, MS 919, Box 25046, Federal Center, Denver, CO 80225 , U.S.A.
}

Even though the depositional environments and lithologies drilled during Leg 122 were unsuitable for the recovery of radiolarian faunas, some of the lithologic types, such as the cherty intervals, could not have been dated without radiolarian biostratigraphy. Radiolarian faunas were recovered from holes drilled at Sites 759 through 764 .

Well-preserved Quaternary radiolarian faunas were recovered from the first few sections at each hole. However, pre-Quaternary faunas were rare due to dissolution. A few poorly preserved Cretaceous radiolarians and questionable Triassic forms were recovered from Hole 759B. Samples from Hole 760A contained a few Eocene to Miocene forms, and poorly preserved lower Mesozoic forms were found in Hole 760B.

Of particular interest are the well-preserved Paleocene faunas from Hole 761B. Many of the Paleocene radiolarian taxa in Cores 122-761B-16X to 122-761B-18X are previously unreported; new forms are discussed and illustrated, and a brief systematic section is included.

Poorly preserved Paleogene and Cretaceous faunas were scattered throughout the samples recovered from the Site 761 mudstones.

Chert and siliceous mudstone fragments were found in Holes $761 \mathrm{~B}, 761 \mathrm{C}$, and $762 \mathrm{C}$, but only one sample from Hole $761 \mathrm{~B}$ and two samples from Hole $761 \mathrm{C}$ contained moderately well-preserved middle and Upper Cretaceous faunas. Brief lithologic descriptions of the cherts are included, and some of the chert samples are illustrated in thin section.

The radiolarian faunas from Sites 762,763 , and 764 are all poorly preserved. Several Paleogene and Cretaceous faunas were recovered from Holes $762 \mathrm{~B}$ and $762 \mathrm{C}$, respectively. Middle and Lower Cretaceous faunas were found in Holes $763 \mathrm{~B}$ and $763 \mathrm{C}$, and questionable Upper Triassic radiolarian fragments were found in a few samples from Holes 764A and 764B.

\section{METHODS OF INVESTIGATION}

\section{SAMPLE PREPARATION}

Most of the radiolarian faunas were studied after the sample was boiled in hydrogen peroxide $(50 \%)$ for 3 to $5 \mathrm{~min}$, 
sieved with 40-, 80-, and 230 -mesh $(420,177$, and $62 \mu \mathrm{m})$ stainless-steel sieves, and treated with hot hydrochloric acid ( $\mathrm{HCl}$; approximately $50 \%$ solution) until the calcareous component was reduced as much as possible. If the sediment did not fully disaggregate, the procedure was repeated. Ultrasound was used when chemical processing did not completely remove the clay component.

The Mesozoic chert samples were processed at the shorebased laboratory using a modification of the hydrofluoric acid (HF) technique of Pessagno and Newport (1972). A small piece (average 4-5 cm in length) of each sample was normally saved for making thin sections. Each sample was first etched with $\mathrm{HCl}$ to determine the calcium carbonate content and then broken (if large) and placed in a Nalgene beaker. Any $\mathrm{CaCO}_{3}$ was then removed by adding approximately $200 \mathrm{~mL}$ of $30 \%$ $\mathrm{HCl}$ to the sample. The sample was washed thoroughly with water, covered with $200-400 \mathrm{~mL}$ of $10 \% \mathrm{HF}$ solution, and allowed to stand for approximately $24 \mathrm{hr}$. After $24 \mathrm{hr}$, the solution was diluted and poured through $40-, 80-$, and 230 mesh sieves. The chert pieces that remained on the 40 -mesh sieve were processed two more times using the same technique. The fine residues were dried in filter paper at low heat and stored in static-free vials.

The Cenozoic residues were stored in water. A small part of the 177 - or $62-\mu \mathrm{m}$ residue was transferred to a glass slide by means of a pipette so as to cover the required area at appropriate density. The preparation was then dried, and a few drops of xylene were added to expel air from the specimens. Slide preparation was completed by the addition of Piccolyte and a glass cover slip.

Quaternary and Cenozoic samples were examined by standard transmitted-light techniques. A reflected-light microscope is customarily used to study Mesozoic faunas because the skeletons are composed of quartz.

\section{Abundance and Preservation}

Determination of relative abundances and state of preservation was attempted only for the Paleocene faunas from Sections 122-761B-16X-1 to 122-761B-19X-CC. Table 1 shows the distribution of Paleocene radiolarian taxa for each sample collected. Abundance is indicated by

$R$ (rare) $=1-49$ specimens/strewn slide;

$\mathrm{F}(\mathrm{few})=50-99$ specimens/strewn slide;

$C($ common $)=100-200$ specimens/strewn slide;

$\mathrm{A}$ (abundant) $=>200$ specimens $/$ strewn slide.

Preservation is indicated by

$\mathbf{P}($ poor $)=$ most specimens are broken or corroded;

$\mathbf{M}$ (moderate) $=$ surficial structures of some specimens are unclear or broken;

$\mathrm{G}(\mathrm{good})=$ most specimens are well preserved.

In the columns showing the occurrence of species, the same abundance symbols are used to indicate the abundance of a given species in the sample's total fauna. Estimates of species abundance were attempted only with strewn slides of normal density in which the radiolarians were not diluted by sedimentary components. The abundance of each species in such a sample is indicated by

$$
\begin{aligned}
& R=1-9 \text { specimens; } \\
& F=10-19 ; \\
& C=20-30 ; \\
& A=>30 .
\end{aligned}
$$

A blank indicates that the species was not found. Sanfilippo and Riedel (1973) suggested that the term "abundant" not be used because it represents an unusually high proportion of a species in an assemblage. However, use of the term abundant is appropriate in this study because certain Paleocene taxa, such as Buryella tetradica, predominate in many of the samples from Cores 122-761B-16X through 122-761B-18X.

\section{BIOSTRATIGRAPHY}

All radiolarian-bearing samples and their respective faunas are discussed for each site. The Leg 122 chert lithology and radiolarian faunas are discussed in another section.

\section{Previous Paleocene Studies}

Few occurrences of Paleocene radiolarian faunas have been reported. Paleocene radiolarian-bearing samples have been recovered from Deep Sea Drilling Project (DSDP) legs at isolated sites in the eastern Atlantic (Nishimura, 1987; Sanfilippo and Riedel, 1979), Gulf of Mexico (Foreman, 1973; Sanfilippo and Riedel, 1973), tropical Pacific (Riedel and Sanfilippo, 1971), off Spain and North Africa (Westberg et al., 1980), and the eastern Indian Ocean (Dumitrică, 1973).

Paleocene radiolarians have been reported from on-land sequences in North America from Missouri (Frizzell and Middour, 1951) and California (Foreman, 1968). Some of the taxa described by Campbell and Clark (1944b) from the Upper Cretaceous of California and by Clark and Campbell (1945) from the Oligocene and Eocene Kreyenhagen Formation also range into the Paleocene. Sanfilippo and Riedel (1976) recorded an occurrence in Cuba. Paleocene radiolarians have also been reported from the USSR by Borisenko $(1958,1960)$, Lipman (1972), and Tochilina (1975).

\section{Radiolarian Biozones}

The Leg 122 Quaternary and rare Tertiary radiolarian faunas were assigned to the detailed biozones proposed by Riedel and Sanfilippo (1978) and later modified by Sanfilippo et al. (1985). These zonal schemes include biozones for the Quaternary Period and Pliocene to Eocene Epochs.

\section{Paleocene}

The Paleocene radiolarians recovered from Site 761 are assignable to the Bekoma campechensis Zone of Nishimura (1987). This zone lies immediately below the Bekoma bidartensis Zone of Foreman (1973) and was considered the "unnamed zone" by Foreman (1973), Sanfilippo and Riedel (1973), and Riedel and Sanfilippo (1978).

The base of the Bekoma campechensis Zone was defined by Nishimura (1987) as the first appearance of Bekoma campechensis Foreman, which is approximately synchronous with the first occurrence of Stylosphaera goruna Sanfilippo and Riedel. The interval from Sample 122-761B-16X-1, 67-69 $\mathrm{cm}$, through Section 122-761B-19X-CC is assigned to this zone. The Bekoma campechensis Zone was tentatively divided by Nishimura (1988) into an upper Peritiviator? sp. A-Diplophlegma sophum Subzone and a lower Pterocodon sp. A-Stylotrochus nitidus Subzone. These subzones are defined by the co-occurrences of these taxa. However, other taxa included within his subzones are not mentioned in Nishimura's abstract. Peritiviator? sp. A, Diplophlegma sophum, and Pterocodon sp. A do not occur in the Hole 761B Paleocene faunas, and Stylotrochus nitidus is rare (Table 1). Individual Hole 761B Paleocene taxa are discussed in "Site 761 ," as well as "Paleocene Radiolarian Taxonomy."

\section{Cretaceous}

No single radiolarian zonal scheme could be used for the Cretaceous radiolarian faunas from the Leg 122 samples. The Cretaceous biozonation proposed by Sanfilippo and Riedel (1985) was based largely on their studies of DSDP and 
ODP material. Upper Cretaceous biozonal data were taken from on-land studies by Pessagno (1976), Taketani (1982), and Yamasaki (1987). Biozonal data for the Leg 122 Lower Cretaceous samples were taken from Schaaf $(1981,1984)$, Baumgartner (1984), and Aita (1987). No attempt was made to zone the fragmental and scarce pre-Cretaceous radiolarians.

\section{Site 759}

\section{Hole $759 B$}

Samples from Hole $759 \mathrm{~B}\left(16^{\circ} 57.25^{\prime} \mathrm{S}, 115^{\circ} 33.61^{\prime} \mathrm{E}\right.$, water depth $2103.0 \mathrm{~m}$ ) on the southeast flank of the Wombat Plateau contain few radiolarians. Sample 122-759B-3R-2, 119-121 cm, contains an undifferentiated Quaternary radiolarian fauna, including Anthocyrtidium angulare, Didymocyrtis tetrathalamus, Stylacontarium acquilonium, and Theocorythium trachelium. Only rare and broken specimens of these taxa occur in Core 122-759B-3R. Section 122-759B-4R-CC is barren of radiolarians. A poorly sorted sandstone in Section 122-759B$5 \mathrm{R}-\mathrm{CC}$ contains reworked Quaternary radiolarians assignable to Stylacontarium acquilonium and broken, poorly preserved collosphaerids.

Radiolarians are absent in Cores 122-759B-6R through 122759B-29R. Section 122-759B-30R-CC contains poorly preserved radiolarians assigned to ?Capnodoce Pessagno; this genus makes its first appearance in Upper Triassic (lower Carnian Stage) sequences. A fragment of the outer ring of Acanthocircus sp. was observed in a strewn slide from Section 122-759B-30R-3. This genus makes its first appearance in Middle Triassic (Ladinian) sequences. Sections 122-759B-31R-CC to 122-759B39R-CC are totally barren of radiolarians.

A dark brown, reworked chert fragment in Sample 122. 759B-30R-1, 3-4 cm, contains a single radiolarian, assignable to Thanarla sp., and a Cretaceous foraminifer. The genus Thanarla Pessagno is restricted to the Cretaceous.

\section{Site 760}

\section{Hole 760A}

Only a few radiolarians were extracted from Hole $760 \mathrm{~A}$ $\left(16^{\circ} 55.32^{\prime} \mathrm{S}, 115^{\circ} 32.48^{\prime} \mathrm{E}\right.$, water depth $\left.1969.7 \mathrm{~m}\right)$, at the top of the Wombat Plateau. Section 122-760A-1H-CC contains rare but fairly well-preserved Quaternary radiolarians assignable to either the Amphirhopalum ypsilon Zone or the Anthrocyrtidium angulare Zone of Sanfilippo et al. (1985). Characteristic taxa include Axoprunum angelinum, Collosphaera huxleyi, Lamprocyrtis nigriniae, Phormostichoartus marylandicus, spyrids (gen. et sp. indet.), Stylacontarium acquilonium, and Stylatractus sp. The faunal composition remains nearly unchanged down to Sample $122-760 \mathrm{~A}-2 \mathrm{H}-5,88-90 \mathrm{~cm}$.

Radiolarians are sporadic from Sections 122-760A-2H-CC to $122-760 \mathrm{~A}-6 \mathrm{H}-\mathrm{CC}$. Fragments of Dorcadospyris spp. were recovered in Section 122-760A-7H-CC, which indicates an age range of middle Miocene to early Oligocene. Rare specimens of Podocyrtis trachoides were found in Sample 122-760A$8 \mathrm{H}-7,29-31 \mathrm{~cm}$, and Spongatractus pachystylus occurs in Section 122-760A-8H-CC; both taxa indicate a middle to late Eocene age. No radiolarians were recovered from Sections $122-760 \mathrm{~A}-9 \mathrm{H}-\mathrm{CC}$ to $122-760 \mathrm{~A}-37 \mathrm{X}-\mathrm{CC}$.

\section{Hole $760 B$}

The sediments from Hole $760 \mathrm{~B}\left(16^{\circ} 55.32^{\prime} \mathrm{S}, 115^{\circ} 32.48^{\prime} \mathrm{E}\right.$, water depth $1969.7 \mathrm{~m}$ ) at the top of Wombat Plateau are nearly devoid of radiolarians. Section 122-760B-2R-CC is barren, but Section 122-760B-3R-CC contains twisted radiolarian spines, as well as poorly preserved, three- and four-rayed forms with outlines similar to those of the Jurassic genera Pseudocrucella
Baumgartner and Homeoparonaella Baumgartner. Three- and four-rayed forms also occur in Upper Triassic (Norian) rocks in western North America (Blome, 1984), but are abundant only in uppermost Triassic (upper Norian) and Lower Jurassic strata. This suggests that Section 122-760B-3R-CC may be as young as Jurassic. Radiolarians are absent from Sections $122-760 \mathrm{~B}-4 \mathrm{R}-\mathrm{CC}$ to $122-760 \mathrm{~B}-29 \mathrm{R}-\mathrm{CC}$.

\section{Site 761}

Site 761 has a Quaternary to upper Oligocene section (Subunit IA, Figs. 1 and 2) that yields sporadic but wellpreserved Quaternary faunas, as well as a Paleocene section (Subunit ID, Fig. 1) that contains well-preserved faunas. The individual Paleocene taxa from Hole 761B are listed in Tables 1 and 2, systematically treated in the "Paleocene Radiolarian Taxonomy" section, and illustrated in Plates 1-4 in this paper.

Subunit IA occurs only in Hole 761B. Subunit ID occurs in both Holes $761 \mathrm{~B}$ and $761 \mathrm{C}$ and is represented by Sections 122-761B-16X through 122-761B-20X and 122-761C-2R (Fig. 1). The cherts recovered from Holes $761 \mathrm{~B}$ and $761 \mathrm{C}$ (Subunits IC, ID, IIB, and IIC, Figs. 2 and 3) are discussed in a later section. A few samples from Subunit IIB to Unit III contain poorly preserved Cretaceous faunas.

\section{Hole $761 \mathrm{~A}$}

Hole $761 \mathrm{~A}$ is at $16^{\circ} 44.23^{\prime} \mathrm{S}, 115^{\circ} 32.10^{\prime} \mathrm{E}$, in a water depth of $2188.8 \mathrm{~m}$ on the central Wombat Plateau.

Section 122-761A-1H-CC contains well-preserved middle to late Quaternary radiolarians, including Acrosphaera spinosa, Anthrocyrtidium ophirense, Axoprunum stauraxonium, Didymocyrtis tetrathalamus, Euchitonia elegans, Giraffospyris angulata, Lamprocyrtis nigriniae, Lamprocyclas spp., and Stylacontarium acquilonium.

\section{Hole $761 B$}

Hole $761 \mathrm{~B}$ is at $16^{\circ} 44.23^{\prime} \mathrm{S}, 115^{\circ} 32.10^{\prime} \mathrm{E}$, in a water depth of $2167.9 \mathrm{~m}$ on the central Wombat Plateau.

Radiolarian faunas assignable to either the upper Quaternary Buccinosphaera invaginita Zone or the Collosphaera tuberosa Zone of Sanfilippo et al. (1985) were extracted from Section 122-761B-1H-CC to Sample 122-761B-2H-4, 138-142 cm. Samples 122-761B-2H-4, 138-142 cm, 122-761B-2H-5, 23-27 cm, 122-761B-2H-CC, and 122-761B-3H-5, 81-83 cm, contain Anthrocyrtidium angulare, Didymocyrtis tetrathalamus, and Theocorythium trachelium, all of which belong within the lower Quaternary Amphirhopalum ypsilon or Anthrocyrtidium angulare Zones of Sanfilippo et al. (1985). Radiolarians are rare and preserved as fragments in Sections 122-761B-6H-CC and 122-761B-7H-CC.

A poorly preserved middle Eocene fauna (Theocotyle cryptocephala to Podocyrtis ampla Zones of Sanfilippo et al., 1985), including Podocyrtis sinuosa and Podocyrtis spp., was recovered from Section 122-761B-8H-CC. Core-catcher samples from Cores 122-761B-9H through 122-761B-11X and 122-761B-14X are barren.

Samples 122-761B-16X-1, 67-69 cm, through Section 122761B-19X-CC (Fig. 2) contain moderately to well-preserved lower to upper Paleocene radiolarian taxa (Table 2). Some of these taxa were first described by Foreman (1973) and Sanfilippo and Riedel (1973; see "Paleocene Radiolarian Taxonomy"') in their studies of radiolarians from DSDP Leg 10 (Gulf of Mexico). However, nearly one-third of the taxa in the Leg 122 Paleocene radiolarian faunas have not previously been illustrated or discussed.

The radiolarian faunas from Samples 122-761B-16X-1, $67-69 \mathrm{~cm}$, to $122-761 \mathrm{~B}-16 \mathrm{X}-4,134-136 \mathrm{~cm}$, are tentatively correlated with the upper Paleocene nannofossil Zone NP9 
Table 1. Estimated abundance and preservation of radiolarian faunas from Sections 122-761B-16X-1 to 122-761B-19X-CC.

\begin{tabular}{|c|c|c|c|c|c|c|c|c|}
\hline Core-Section & $\begin{array}{c}\text { Interval } \\
(\mathrm{cm})\end{array}$ & $\begin{array}{l}\text { Abundance/ } \\
\text { Preservation }\end{array}$ & 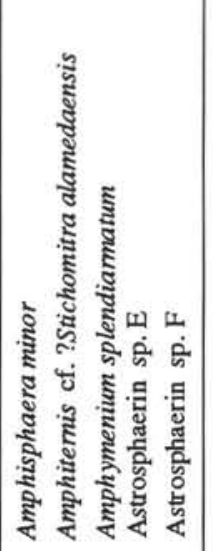 & 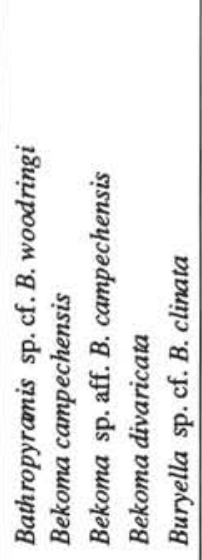 & 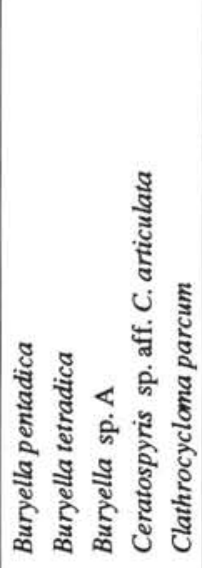 & 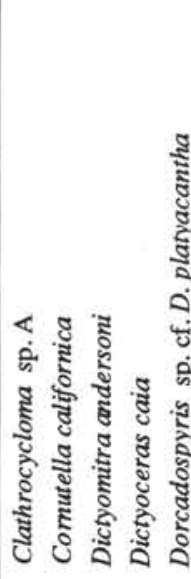 & 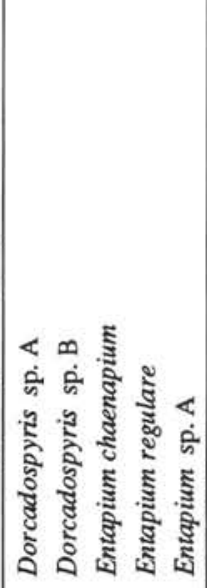 & 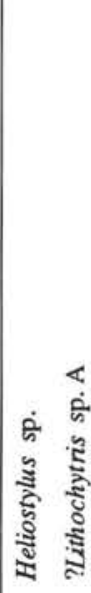 \\
\hline $16 \mathrm{X}-01$ & $67-69$ & $\mathrm{R} / \mathrm{M}$ & & & $\mathbf{R}$ & & $\mathrm{R}$ & \\
\hline $16 \mathrm{X}-02$ & $67-69$ & $\mathrm{R} / \mathrm{M}$ & & & $\mathrm{R}$ & & $\mathrm{R}$ & \\
\hline $16 \mathrm{X}-03$ & $67-69$ & $\mathrm{R} / \mathrm{M}$ & & & R R & & $\mathrm{R}$ & \\
\hline $16 \mathrm{X}-04$ & $67-69$ & $\mathrm{R} / \mathrm{M}$ & $\mathrm{R}$ & $\mathrm{R}$ & $\mathrm{R} R$ & $\mathrm{R}$ & $\mathrm{R}$ & \\
\hline $16 \mathrm{X}-04$ & $97-100$ & $\mathrm{R} / \mathrm{M}$ & & & $\mathrm{R} \mathrm{R}$ & & & \\
\hline $16 \mathrm{X}-\mathrm{CC}$ & & $\mathrm{A} / \mathrm{G}$ & F F & $\begin{array}{llll} & F & F & C \\
\end{array}$ & $\mathrm{~F} \quad \mathrm{C} \quad \mathrm{F} \quad \mathrm{F}$ & $\mathrm{F} F$ & $C \mathrm{~F} F \mathrm{C} F$ & $\mathrm{~F}$ \\
\hline $17 \mathrm{X}-01$ & $67-69$ & $\mathrm{~A} / \mathrm{G}$ & \begin{tabular}{lll|}
$F$ & $F$ & $F$ \\
\end{tabular} & 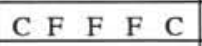 & C $\quad C \quad F \quad F \quad F$ & $\mathrm{~F} F$ & $C F$ F $C F$ & $\mathrm{~F}$ \\
\hline $17 X-01$ & $133-136$ & $\mathrm{~A} / \mathrm{G}$ & C $\quad$ C F F & $\mathrm{C} C \mathrm{C} \quad \mathrm{F} \quad \mathrm{C}$ & C C $\mathrm{C} F \quad \mathrm{~F}$ & C C & $\mathrm{C} F \mathrm{~F} \quad \mathrm{C} F$ & $\mathrm{~F}$ \\
\hline $17 \mathrm{X}-02$ & $67-69$ & $\mathrm{~A} / \mathrm{G}$ & $\begin{array}{llll}\text { C } & \text { F } & \text { F } & \text { C } \\
\end{array}$ & F F F $\quad$ C & C $\mathrm{C} \quad \mathrm{F}$ & $\mathrm{C} \mathrm{F}$ & $\mathrm{C} F \mathrm{~F} \quad \mathrm{C} C$ & $\mathrm{~F} F$ \\
\hline $17 X-02$ & 133-136 & $\mathrm{A} / \mathrm{G}$ & \begin{tabular}{lll|}
$F$ & $F$ & $F$ \\
\end{tabular} & $\mathrm{~F} F \mathrm{~F}$ & C A & C F $\quad F \quad C$ & $C \quad F \quad F \quad F \quad F$ & $\mathrm{~F} F$ \\
\hline $17 \mathrm{X}-03$ & $67-69$ & $\mathrm{C} / \mathrm{M}$ & F F F & C & C C F & $C \quad F \quad R \quad F \quad C$ & $C F F C F$ & F C \\
\hline $17 X-03$ & $133-136$ & $\mathrm{C} / \mathrm{M}$ & $\mathrm{F} \quad \mathrm{F} F \mathrm{~F}$ & F R & C C F & 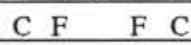 & $C F \quad F \quad F \quad F$ & F C \\
\hline $17 X-04$ & $67-69$ & $\mathrm{C} / \mathrm{M}$ & $\begin{array}{llllll} & \mathrm{R} & \mathrm{F} & \mathrm{F} & \mathrm{C} & \mathrm{C} \\
\end{array}$ & C & C C F & 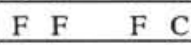 & $C F \quad F \quad F \quad F$ & F C \\
\hline $17 \mathrm{X}-05$ & $67-69$ & $\mathrm{C} / \mathrm{M}$ & $\mathrm{F} \quad \mathrm{R} \quad \mathrm{C} \quad \mathrm{F} \quad \mathrm{F}$ & $\mathrm{C}$ & C C F & $\mathrm{F} C$ & $C F \quad F \quad C F$ & $\mathrm{C}$ \\
\hline $17 \times-06$ & $67-69$ & $\mathrm{C} / \mathrm{M}$ & $\begin{array}{llllll} & \mathrm{R} & \mathrm{F} & \mathrm{C} & \mathrm{C} & \\
\end{array}$ & $\mathrm{C}$ & $\mathrm{F} \quad \mathrm{C} \quad \mathrm{R}$ & $\mathrm{F} \quad \mathrm{C} \quad \mathrm{R}$ & C $\quad F \quad F \quad F$ & $\mathrm{C}$ \\
\hline $17 X-06$ & 133-136 & $\mathrm{C} / \mathrm{M}$ & R $\quad F \quad C F$ & $\mathrm{C}$ & C A F & R F & $\mathrm{F} \quad \mathrm{C} \quad \mathrm{R}$ & $\mathrm{F}$ \\
\hline $17 \mathrm{X}-\mathrm{CC}$ & & $\mathrm{C} / \mathrm{M}$ & $\mathrm{F} \quad \mathrm{F} C \mathrm{C} F$ & $\mathrm{C}$ & C A F & $\mathrm{F} \quad \mathrm{C} \quad \mathrm{R}$ & C $\quad F \quad C \quad R$ & $\mathrm{C}$ \\
\hline $18 \mathrm{X}-01$ & $67-69$ & $\mathrm{C} / \mathrm{M}$ & R $\quad F \quad C \quad R$ & $\mathrm{R}$ & $\mathrm{F} C \mathrm{C} \quad \mathrm{F}$ & R F & $C R \quad F \quad C R$ & $\mathrm{C}$ \\
\hline $18 \times-02$ & $67-69$ & $\mathrm{C} / \mathrm{M}$ & R $\quad F \quad F \quad R$ & R R & C $C \mathrm{R} \mathrm{R}$ & $\mathrm{R} \mathrm{F}$ & C $\quad F \quad C \quad R$ & $\mathrm{C}$ \\
\hline $18 \mathrm{X}-03$ & $67-69$ & $\mathrm{C} / \mathrm{M}$ & $\begin{array}{llllll} & R & F & F & R \\
\end{array}$ & $\mathrm{R}$ & 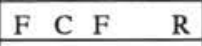 & $\mathrm{F} F$ & C $\quad R \quad F \quad F \quad R$ & $\mathrm{~F}$ \\
\hline $18 X-04$ & $67-69$ & $\mathrm{~A} / \mathrm{G}$ & C $\quad \mathrm{R} \quad \mathrm{C} \quad \mathrm{F} \quad \mathrm{C}$ & 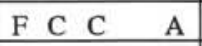 & A $A$ A $\quad$ C $\quad F \quad A$ & C C & A $\quad R \quad C \quad C \quad F$ & $\mathrm{C}$ \\
\hline $18 X-05$ & $67-69$ & $\mathrm{~A} / \mathrm{G}$ & $C \quad F \quad C \quad C \quad F$ & $\mathrm{~F} F \quad \mathrm{C} \quad \mathrm{R} C$ & C A $\quad$ C $\quad$ R A & $\mathrm{F} F$ & C $\quad F \quad C F$ & $\mathrm{C}$ \\
\hline $18 \mathrm{X}-06$ & $67-69$ & $\mathrm{~A} / \mathrm{G}$ & $\mathrm{F} \quad \mathrm{R} \quad \mathrm{F} \quad \mathrm{C} \quad \mathrm{C}$ & C R R C & C A F A & $\mathrm{F} \mathrm{F}$ & $\mathrm{F} C \mathrm{~F}$ & C \\
\hline $18 \mathrm{X}-\mathrm{CC}$ & & $\mathrm{A} / \mathrm{G}$ & $\begin{array}{llllll} & \mathrm{R} & \mathrm{F} & \mathrm{C} & \mathrm{C} & \\
\end{array}$ & C R R & C C & F F & $\mathrm{F} C \mathrm{~F}$ & $\mathrm{~F}$ \\
\hline $19 \mathrm{X}-01$ & $74-79$ & $\mathrm{C} / \mathrm{G}$ & $\mathrm{F} \quad \mathrm{F} F$ & R F & F C & $\mathrm{R}$ & R F & \\
\hline $19 \mathrm{X}-01$ & $134-136$ & $\mathrm{R} / \mathrm{M}$ & $\mathrm{R} \mathrm{R}$ & R F & R F & $\mathrm{F}$ & R R & \\
\hline $19 \mathrm{X}-02$ & $72-74$ & $\mathrm{R} / \mathrm{M}$ & $\mathrm{R} \mathrm{R}$ & $\mathrm{R}$ & $\mathrm{R} \mathrm{R}$ & $\mathrm{R}$ & $\mathbf{R}$ & \\
\hline 19X-CC & & $\mathrm{R} / \mathrm{P}$ & & & & & $\mathrm{R}$ & \\
\hline
\end{tabular}

Note: Letter codes explained in text.

(zones of Martini, 1971; Table 2); samples from the interval from Section 122-761B-16X-CC to Sample 122-761B-17X-1, 133-136 cm, are correlated with Zones NP7-8; Samples 122$761 \mathrm{~B}-17 \mathrm{X}-2,134-136 \mathrm{~cm}$, to $122-761 \mathrm{~B}-17 \mathrm{X}-5,134-136 \mathrm{~cm}$, are correlated with Zone NP6; and Samples 122-761B-17X-6, $134-136 \mathrm{~cm}$, to $122-761 \mathrm{~B}-19 \mathrm{X}-3,134-136 \mathrm{~cm}$, are correlated with Zone NP5 (Table 2; also Siesser and Bralower, this volume). The faunas from Samples 122-761B-19X-4, 134-136 $\mathrm{cm}$, to $122-761 \mathrm{~B}-21 \mathrm{X}-2,134-136 \mathrm{~cm}$, are tentatively correlated with the lower Paleocene nannofossil Zone NP3-4 (Shipboard Scientific Party, 1990, p. 180). However, the exact position of the transition between nannofossil zones in each section is not clear in the Leg 122 Initial Reports volume. Furthermore, Core 122-761B-16X consists of only four sections and a core catcher in the detailed barrel sheets, yet five sections are indicated in the text (Shipboard Scientific Party, 1990 , cf. p. 498 , and p. 181 , fig. 23 ).

Nannofossil Zones NP9 to NP4 can be tentatively correlated with the concurrent ranges of Paleocene taxa from Hole 761B (Table 2). The abrupt appearance (downhole) of 22 Paleocene taxa in Section 122-761B-16X-CC may be the result of the difference in preservation between Sample 122-761B- 
Table 1 (continued).

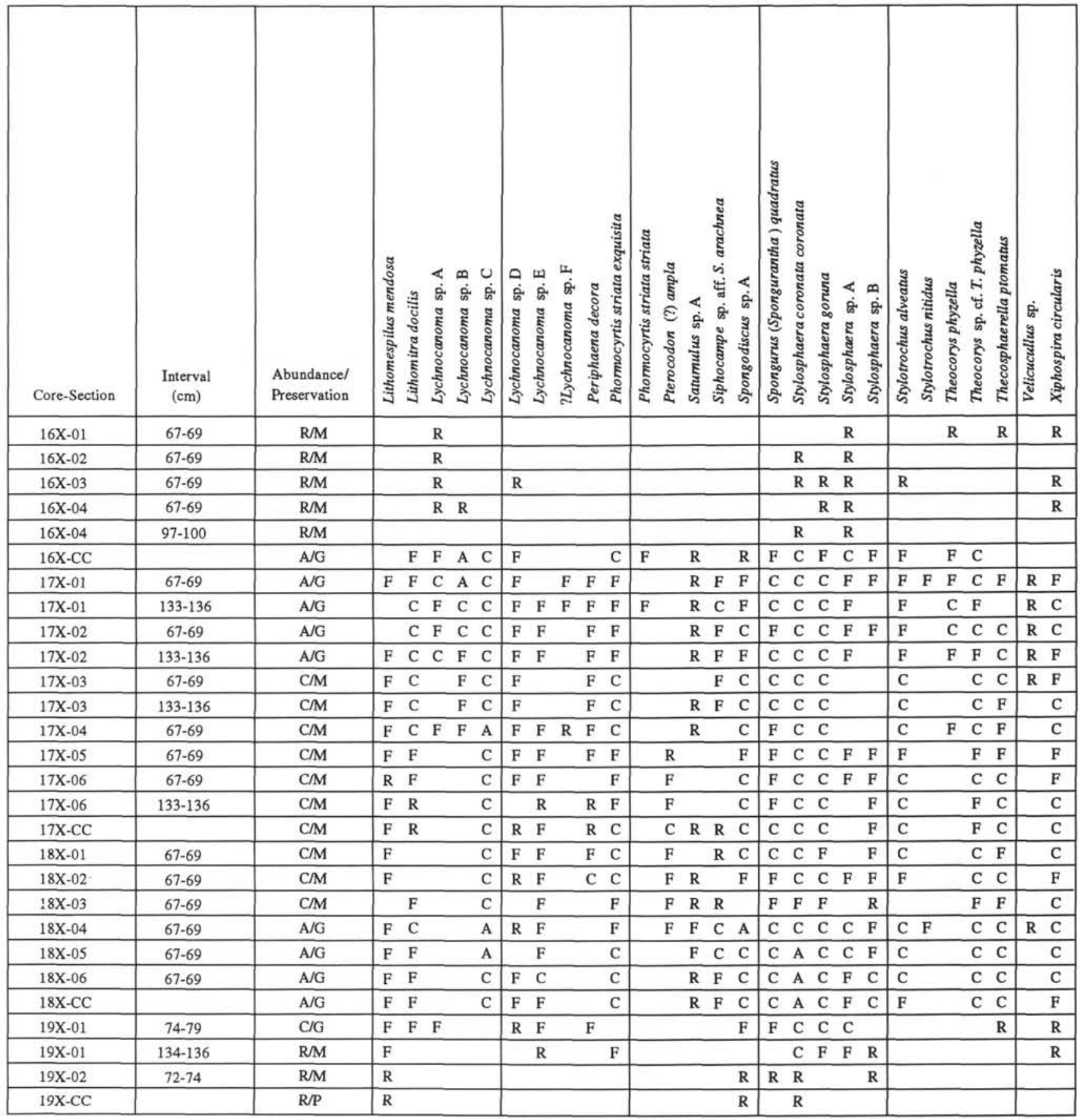

$16 \mathrm{X}-4,97-100 \mathrm{~cm}$, a sample containing rare and fragmental forms, and Section 122-761B-16X-CC, which contains abundant and well-preserved forms. This appearance also occurs near the boundary between nannofossil Zones NP9 and NP7-8. Phormocyrtis striata striata appears to be restricted to the interval defined by nannofossil Zones NP7-8. The taxa that make their first and final appearances downhole in the interval correlated with nannofossil Zone NP6 include Dictyoceras caia and Heliostylus sp. (Table 2). The sample data show that Pterocodon (?) ampla makes its first appearance in Section 122-761B-17X-5 and that Theocorys phyzella makes its final appearance in Sample 122-761B-17X-4, 67-69 cm; both of these samples are correlated with the main body of nannofossil Zone NP6.

Forty-eight of 54 Paleocene taxa studied make their last appearance (downhole) in Sample 122-761B-19X-2, 67-69 cm, which is correlated with the lowest part of nannofossil Zone NP5. This abrupt disappearance below Sample 122-761B$19 \mathrm{X}-2,72-74 \mathrm{~cm}$, is probably the result of the change in preservation between Sample 122-761B-19X-2, 72-74 cm, and Section 122-761B-19X-CC (Table 1).

No radiolarians were recovered from Cores 122-761B-20X to 122-761B-24X. Fragments of Dictyomitra spp. and Phaseliforma spp. were recovered in Section 122-761B-25X-CC; 


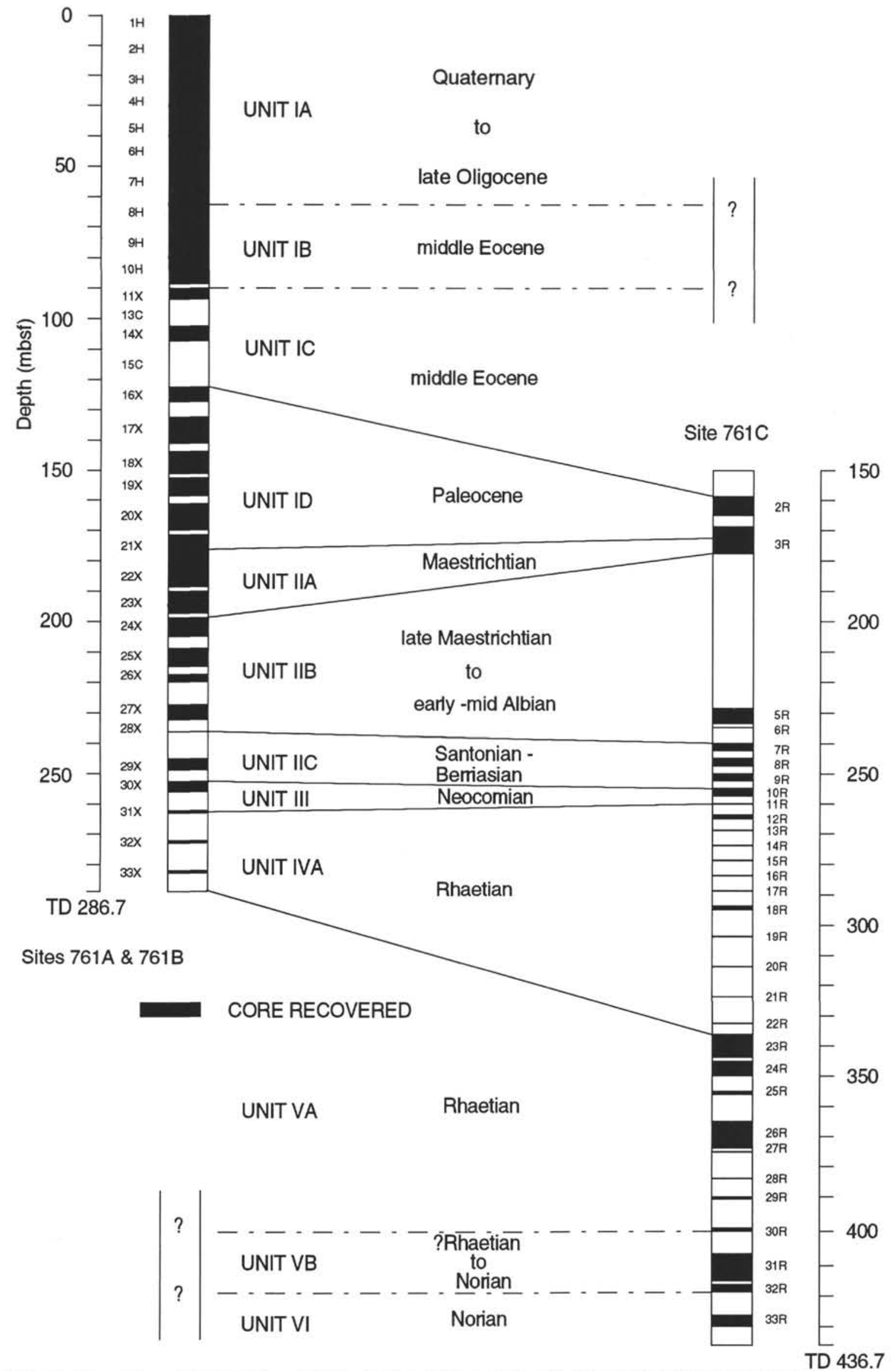

Figure 1. Correlation of Holes $761 \mathrm{~A}$ and $761 \mathrm{~B}$ with Hole $761 \mathrm{C}$, including lithologic units and approximate ages. 


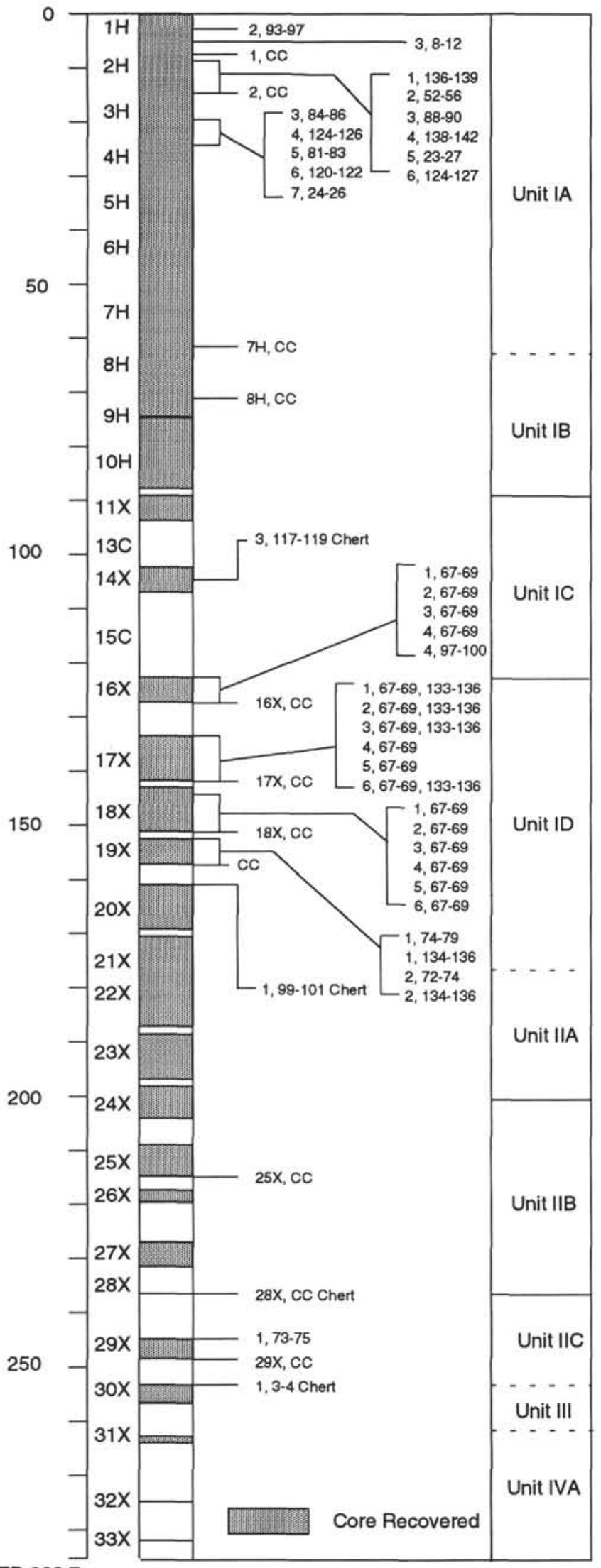

TD 286.7

Figure 2. Detailed correlation of cores and lithologic units for Hole $761 \mathrm{~B}$, including radiolarian-bearing samples and chert intervals.

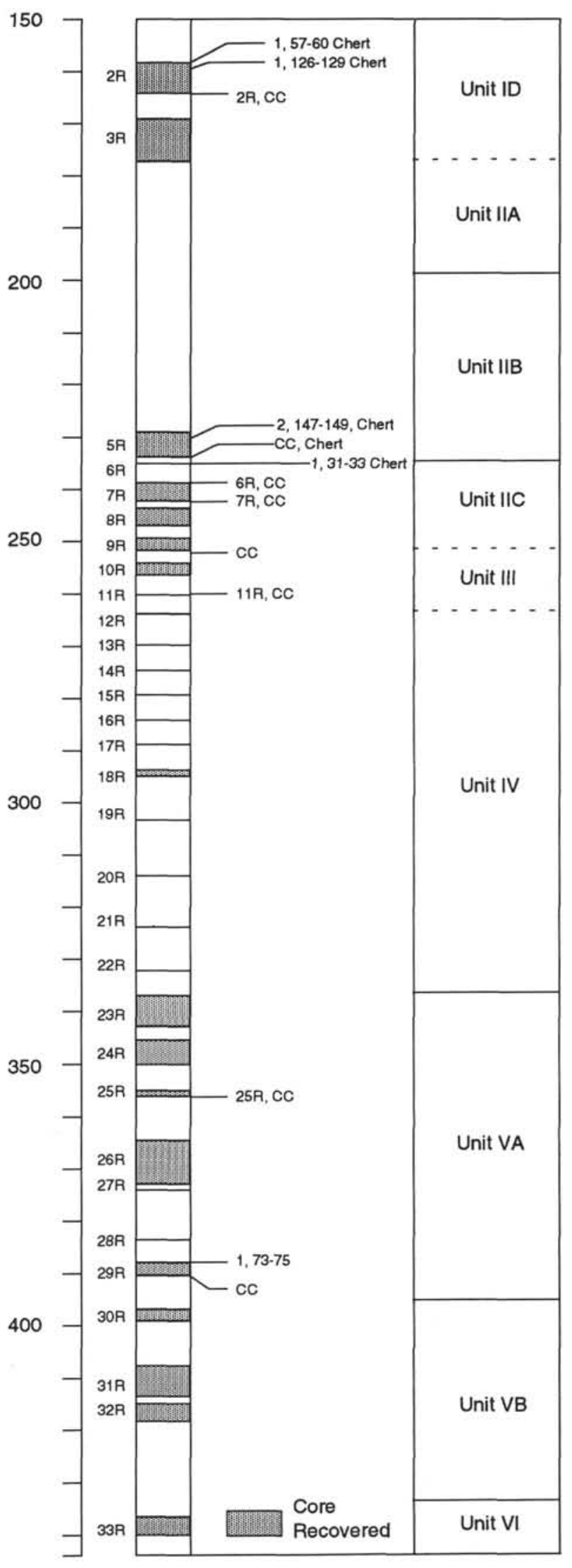

TD 436.7

Figure 3. Detailed correlation of cores and lithologic units for Hole $761 \mathrm{C}$, including radiolarian-bearing samples and chert intervals. 
Table 2. Correlation of the relative ranges of radiolarian taxa from Sections 122-761B-16X-1 to 122-761B19X-CC to nannofossil Zones NP9 to NP3-4.

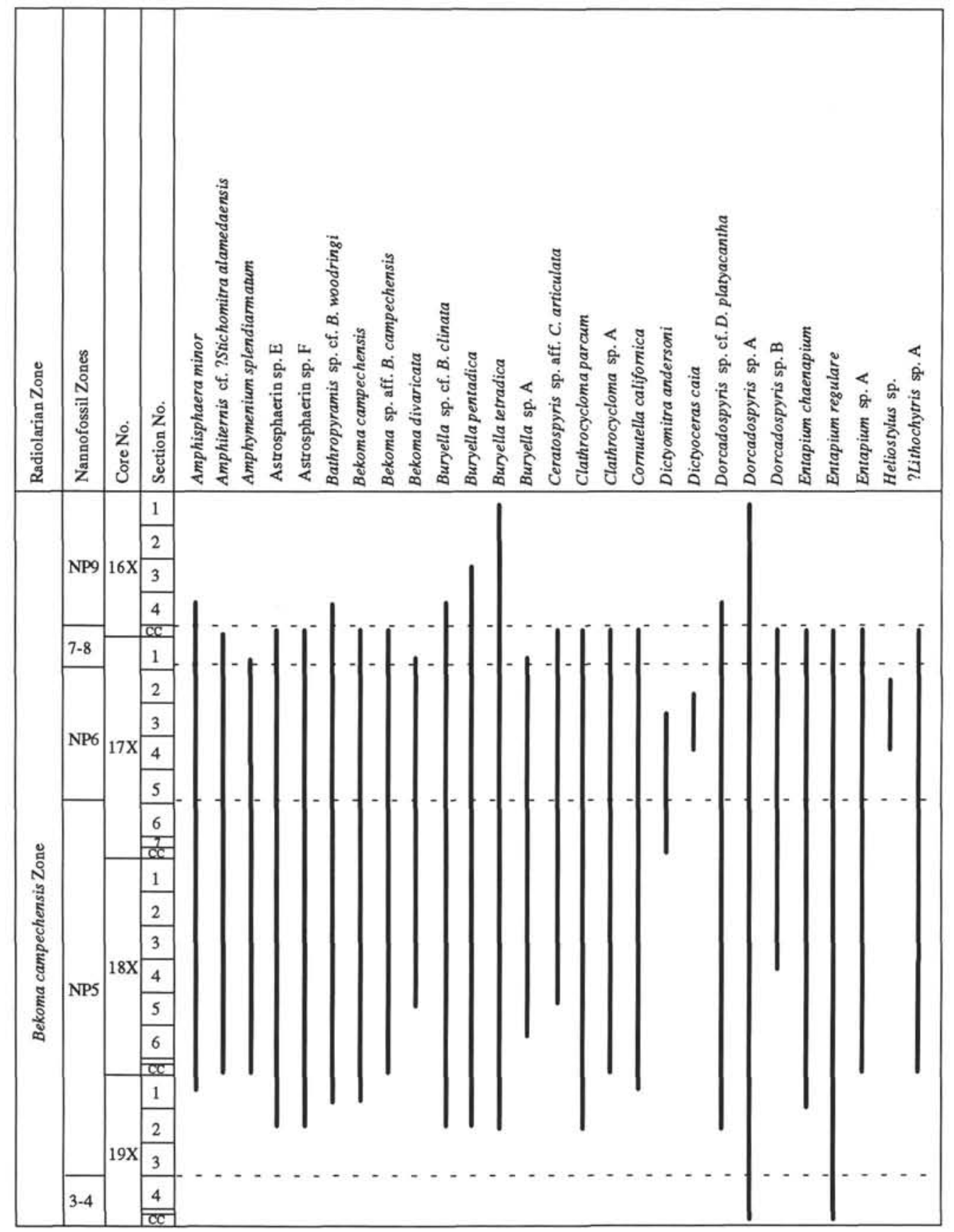

these indicate a Late Cretaceous (Campanian?) age. Cores 122-761B-26X and 122-761B-27X are barren.

Sample 122-761B-29X-1, 73-75 cm, contains a poorly preserved lower to middle Aptian fauna assignable to either the Stichomitra euganea Zone or the lowermost part of the Acaeniotyle umbilicata Zone of Sanfilippo and Riedel (1985). Agediagnostic taxa include Eucyrtis micropora, Pseudodictyomitra carpatica, P. lodogaensis, Sethocapsa trachyostraca, Stichomitra spp., Theocorys antiqua, and Xitus alievi. Section 122-761B$29 \mathrm{X}-\mathrm{CC}$ contains mostly casts, but it also includes poorly preserved forms belonging to Praeconocaryomma Pessagno, Pseudodictyomitra Pessagno, Stichomitra Cayeux, and Tha- narla Pessagno. The concurrent ranges of these genera indicate an undifferentiated late Early Cretaceous age. Sections 122761B-30X-CC to 122-761B-33X-CC are barren.

\section{Hole $761 C$}

With the exception of Section 122-761C-2R-CC (Fig. 3), most of the sediments contain poorly preserved faunas in Hole 761C $\left(16^{\circ} 44.23^{\prime} \mathrm{S}, 115^{\circ} 32.10^{\prime} \mathrm{E}\right.$, water depth $\left.2167.9 \mathrm{~m}\right)$ on the central Wombat Plateau. However, this section contains rare but moderately preserved upper Paleocene radiolarians nearly identical to those from Sections 122-761B-16X and 122-761B-17X. Sections 122-761C-3R-CC and 122-761C-9R-CC are barren. 
Table 2 (continued).

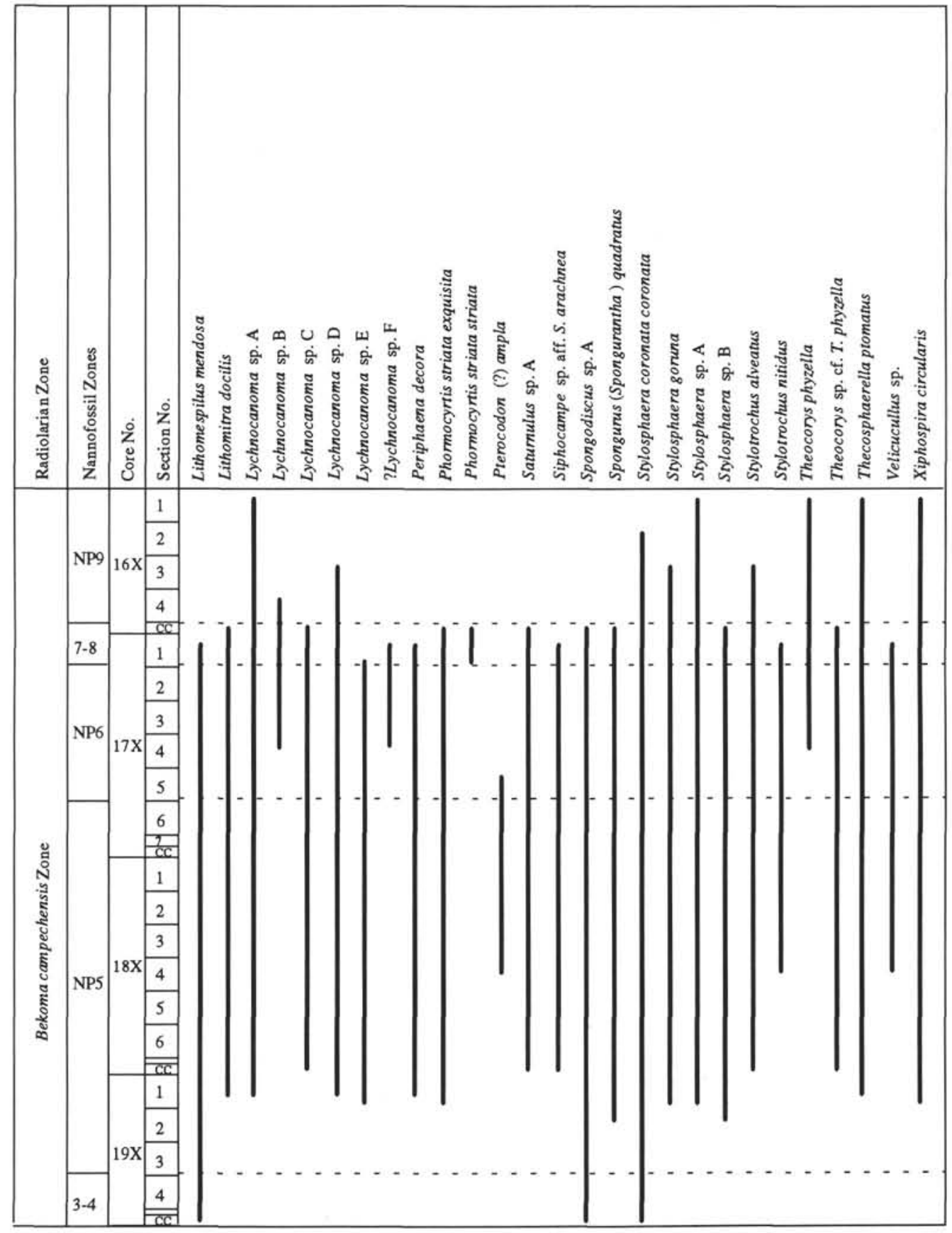

Chert Samples 122-761C-5R-2, 147-149 cm, and 122761C-6R-1, 31-33 cm, (Fig. 3) contain identifiable radiolarian faunas, both of which are discussed in a separate section.

Nearly all the radiolarians from Section 122-761C-7R-CC are preserved as casts; few or no external structures remain. However, several forms could be identified as Mita sp. cf. $M$. magnifica and Xitus sp. cf. X. spicularius, both of which indicate an undifferentiated late Early Cretaceous (AptianAlbian) age. Section 122-761C-11R-CC contains a poorly preserved fauna containing ?Holocryptocanium sp. and ?Obesacapsula sp., which suggest an undifferentiated Early
Cretaceous age. Cores $122-761 \mathrm{C}-23 \mathrm{R}-23 \mathrm{R}$ to $122-761 \mathrm{C}-30 \mathrm{R}$ are barren.

Site 762

Hole $762 A$

One faunal assemblage was recovered from Hole 762A $\left(19^{\circ} 53.23^{\prime} \mathrm{S}, 112^{\circ} 15.24^{\prime} \mathrm{E}\right.$, water depth $\left.1359.9 \mathrm{~m}\right)$ on the western part of central Exmouth Plateau. Section 122-762A$1 \mathrm{H}-\mathrm{CC}$ contains rare, well-preserved radiolarians of undifferentiated Quaternary age, including Acrosphaera spinosa, 
Didymocyrtis prismatica, Lamprocyclas maritalis, Lamprocyrtis sp. cf. L. nigriniae, and Theocorythium trachelium.

\section{Hole $762 B$}

Quaternary radiolarian faunas are well represented in Hole $762 \mathrm{~B}\left(19^{\circ} 53.24^{\prime} \mathrm{S}, 112^{\circ} 15.24^{\prime} \mathrm{E}\right.$, water depth $\left.1360.0 \mathrm{~m}\right)$ on the western part of central Exmouth Plateau. Samples $122-762 \mathrm{~B}-1 \mathrm{H}-1,90-92 \mathrm{~cm}$, to $122-762 \mathrm{~B}-1 \mathrm{H}-3,90-92 \mathrm{~cm}$, all contain radiolarians assignable to the upper Quaternary Buccinosphaera invaginita Zone of Sanfilippo et al. (1985). The biostratigraphically diagnostic taxa include Buccinosphaera invaginita, Didymocyrtis tetrathalamus, Lamprocyrtis nigriniae, and Stylacontarium acquilonium. Section 122-762B-1H-CC contains moderately preserved radiolarians assignable to either the upper Quaternary Buccinos phaera invaginita Zone or the Collosphaera tuberosa Zone (Sanfilippo et al., 1985). Key marker taxa include Acrosphaera spinosa, Collosphaera tuberosa, Lamprocyrtis nigriniae, Stylacontarium acquilonium, and Theocorythium trachelium. The interval from Sample 122-762B-2H-1, 76-78 $\mathrm{cm}$, to Section 122-762B-2H-CC contains undifferentiated mid-Quaternary radiolarians, including Axoprunum angelinum, Anthrocyrtidium spp., Phormostichoartus doliolum, and Theocorythium trachelium. Radiolarians assignable to the lower Quaternary Amphirhopalum ypsilon or Anthrocyrtidium angulare Zones of Sanfilippo et al. (1985) were extracted from Samples 122-762B-3H-1, 74-76 cm, to 122 762B-3H-5, 74-76 cm. Sections 122-762B-3H-CC to 122 762B-17H-CC are barren of radiolarians.

\section{Hole $762 C$}

Hole $762 \mathrm{C}$ is also on the western part of central Exmouth Plateau, at $19^{\circ} 53.23^{\prime} \mathrm{S}, 112^{\circ} 15.24^{\prime} \mathrm{E}$, in a water depth of 1360.0 m.

Sections 122-762C-2X-CC and 122-762C-3X-CC are barren of radiolarians. Sample $122-762 \mathrm{C}-4 \mathrm{X}-3,75-77 \mathrm{~cm}$, contains the lower Oligocene marker taxon Theocyrtis tuberosa. Section 122-762C-4X-CC contains a relatively well-preserved fauna assignable to the upper Eocene Thyrsocyrtis bromia Zone of Sanfilippo et al. (1985). The key marker taxa include Carpocanistrum azyx, Dictyopora pirum, and Theocyrtis tuberosa, as well as undescribed species of Axoprunum and Theocotyle. Sections 122-762C-5X-CC to $122-$ 762C-19X-CC are barren. Sample 122-762C-20X-3, 74-76 $\mathrm{cm}$, and Section 122-762C-20X-CC contain poorly preserved lower Eocene radiolarians assignable to the Buryella clinata Zone of Sanfilippo et al. (1985), including undescribed Axoprunum species, Buryella clinata, B. tetradica, Calocycloma castrum, Podocyrtis papalis, and Spongatractus sp. cf. $S$. balbis.

Although Sections 122-762C-21X-CC to $122-762 \mathrm{C}-42 \mathrm{X}-\mathrm{CC}$ contain fragments of siliceous microfossils, they are too poorly preserved to be biostratigraphically useful. Sections $122-762 \mathrm{C}-43 \mathrm{X}-\mathrm{CC}$ and $122-762 \mathrm{C}-45 \mathrm{X}-\mathrm{CC}$ yielded poorly preserved Maestrichtian or Campanian radiolarians, including Dictyomitra sp. cf. D. densicostata and specimens of Phaseliforma Pessagno. Sections 122-762C-46X-CC, 122-762C-47XCC, 122-762C-58X-CC, and 122-762C-64X-CC all contain poorly preserved forms identifiable as undifferentiated Late Cretaceous age. Section 122-762C-44X-CC and most sections from $122-762 \mathrm{C}-48 \mathrm{X}-\mathrm{CC}$ to $122-762 \mathrm{C}-63 \mathrm{X}-\mathrm{CC}$ not mentioned previously are barren. An undifferentiated Early Cretaceous age was assigned to Section 122-762C-66X-CC on the basis of forms belonging to Pseudodictyomitra Pessagno. With the exception of Section 122-762C-79X-CC, which contains forms assignable only to Pseudodictyomitra Pessagno and Stichomitra Cayeux of undifferentiated Early Cretaceous age, the remaining sections from Core $122-762 \mathrm{C}-67 \mathrm{X}$ to Section 122 762C-89X-CC are barren.

\section{Site 763}

\section{Hole $763 A$}

Radiolarian recovery was generally poor and most of the faunas are of low abundance at Hole $763 \mathrm{~A}\left(20^{\circ} 35.20^{\prime} \mathrm{S}\right.$, $112^{\circ} 12.50^{\prime} \mathrm{E}$, water depth $1367.5 \mathrm{~m}$ ) on the western part of central Exmouth Plateau. Samples 122-763A-2H-2, 60-62 cm, and $122-763 \mathrm{~A}-2 \mathrm{H}-5,60-62 \mathrm{~cm}$, and Section 122-763A-2H-CC all contain common and well-preserved upper Quaternary radiolarians assignable to the Collosphaera tuberosa Zone of Sanfilippo et al. (1985). Individual taxa include Acrosphaera spinosa, Anthrocyrtidium spp., Collosphaera tuberosa, Didymocyrtis tetrathalamus, Lamprocyrtis nigriniae, Phormostichoartus corbula, P. marylandicus, and Stylacontarium acquilonium. Sample 122-763A-3H-2, 60-62 cm, yielded a sparse, mixed middle Quaternary fauna that includes taxa indicating the Collosphaera tuberosa and Amphirhopalum ypsilon Zones of Sanfilippo et al. (1985). Sections 122-763A$3 \mathrm{H}-\mathrm{CC}$ through $122-763 \mathrm{~A}-21 \mathrm{H}-\mathrm{CC}$ are barren.

\section{Hole $763 B$}

Many of the samples from Hole 763B $\left(20^{\circ} 35.19^{\prime} \mathrm{S}\right.$, $112^{\circ} 12.52^{\prime} \mathrm{E}$, water depth $1367.5 \mathrm{~m}$ ) on the western part of central Exmouth Plateau contain unidentifiable radiolarians that are preserved as clear, silica-infilled balls and cones with little or no exterior meshwork remaining. Sections 122-763B-2X-CC through 122-763B-9X-CC are barren. The uppermost occurrence of Cretaceous taxa is in Section 122-763B-10X-CC, which contains forms identifiable only to the generic level; these include Artostrobium sp. and Phaseliforma sp. Sections 122-763B$11 \mathrm{X}-\mathrm{CC}$ through 122-763B-21X-CC are barren.

Most of the radiolarian samples from Hole 763B are Cretaceous in age. Poorly preserved middle Cretaceous forms assignable only to the genera Dictyomitra Zittel and Stichomitra Cayeux were recovered from Sample 122-763B-22X-1, 60-62 $\mathrm{cm}$. Section 122-763B-22X-CC contains common but poorly preserved radiolarians assignable to the upper Cenomanianlower Turonian part of the Obesacapsula somphedia Zone of Sanfilippo and Riedel (1985); identifiable forms include Alievium spp., Pseudoaulophacus spp., Pseudodictyomitra pseudomacrocephala, Stichomitra communis, Stichomitra spp., and Thanarla veneta. The fauna from Sample 122-763B-23X-1, 60-62 $\mathrm{cm}$, is sparse but it does possess Thanarla veneta of Cenomanian or Turonian age. Sections 122-763B-24X-CC through 122-763B$30 \mathrm{X}-\mathrm{CC}$ are barren. The presence of Thanarla sp. in Section $122-763 \mathrm{~B}-31 \mathrm{X}-\mathrm{CC}$ indicates an undifferentiated Valanginian to Cenomanian age. Sections 122-763B-32X-CC through 122-763B$36 \mathrm{X}-\mathrm{CC}$ are all barren.

Section 122-763B-37X-CC contains moderately preserved Lower Cretaceous (Albian) radiolarians assignable to the lower part of the Acaeniotyle umbilicata Zone of Sanfilippo and Riedel (1985). The biostratigraphically diagnostic taxa include Archaeodictyomitra simplex and Thanarla pulchra. Sections 122-763B-38X-CC, 122-763B-41X-CC, and 122 763B-42X-CC all contain poorly preserved forms belonging to the long-ranging Cretaceous radiolarian genera Cryptoamphorella Dumitrică, Pantanellium Pessagno, Pseudodictyomitra Pessagno, Stichomitra Cayeux, and Thanarla Pessagno. Forms assignable to Acaeniotyle diaphorogona and Thanarla sp. were recovered from Sample 122-763B-39X-1, 60-62 cm. Acaeniotyle diaphorogona has an age range of Berriasian to middle Albian. Sections 122-763B-39X-CC and 122-763B$43 \mathrm{X}-\mathrm{CC}$ to $122-763 \mathrm{~B}-54 \mathrm{X}-\mathrm{CC}$ are all barren, with the exception of Section 122-763B-47X-CC and Sample 122-763B- 
$48 \mathrm{X}-1,60-62 \mathrm{~cm}$, which both contain poorly preserved upper Valanginian to Aptian radiolarians identifiable as Cryptoamphorella sp., Pseudodictyomitra sp. aff. P. leptoconica, and Thanarla (?) conica. Sample 122-763B-48X-5, 60-62 cm, contains? Obesacapsula sp., Pseudodictyomitra leptoconica, Syringocapsa sp., and Thanarla sp., all of which indicate a probable Valanginian age.

\section{Hole $763 C$}

Only two samples yielded radiolarians from Hole $763 \mathrm{C}$ $\left(20^{\circ} 35.21^{\prime} \mathrm{S}, 112^{\circ} 12.51^{\prime} \mathrm{E}\right.$, water depth $\left.1367.5 \mathrm{~m}\right)$ on the western part of central Exmouth Plateau. Sections 122-763C$2 \mathrm{R}-\mathrm{CC}$ through $122-763 \mathrm{C}-46 \mathrm{R}-\mathrm{CC}$ are all barren, with two exceptions. Section 122-763C-22R-CC contains poorly preserved forms (Archaeodictyomitra apiara and Thanarla (?) conica) that indicate an undifferentiated Berriasian to late Valanginian age. The fauna in Section 122-763C-35R-CC is completely replaced by pyrite, and most of the radiolarians are preserved as casts and molds. Identifiable taxa include ?Mirifusus sp., Parvicingula (?) jonesi, and Parvicingula sp., which suggest either an Early Cretaceous (Berriasian) or Late Jurassic (Tithonian) age.

\section{Site 764}

\section{Hole $764 A$}

Radiolarians were recovered from only three samples from Hole $764 \mathrm{~A}\left(16^{\circ} 33.96^{\prime} \mathrm{S}, 115^{\circ} 27.43^{\prime} \mathrm{E}\right.$, water depth $\left.2698.6 \mathrm{~m}\right)$ on the northeast part of the Wombat Plateau. Sample 122-764A$1 \mathrm{R}-4,140-142 \mathrm{~cm}$, contains sparse late Quaternary age radiolarians assignable to either the Buccinosphaera invaginita Zone or the Collosphaera tuberosa Zone of Sanfilippo et al. (1985). Section 122-764A-7R-CC contains pyritized casts of partial tests, as well as fragments of radiolarian spines questionably identified as Ferresium Blome. This genus has been reported from Upper Triassic (upper Norian and Rhaetian) sequences in western North America, Japan, and New Zealand (Blome, 1984).

\section{Hole $764 B$}

Hole $764 \mathrm{~B}$ is at $16^{\circ} 33.96^{\prime} \mathrm{S}, 115^{\circ} 27.43^{\prime} \mathrm{E}$, in a water depth of $2698.6 \mathrm{~m}$ on the northeast part of the Wombat Plateau. Section 122-764B-20R-CC contains fragments questionably assigned to Ferresium.

\section{Cherts}

Chert is sporadically present in Holes 761B, 761C, and $762 \mathrm{C}$. Of the 10 chert samples examined for radiolarians, only three (Samples 122-761B-28X-CC, 14-16 cm; 122-761C-5R-2, 147-149 cm; and 122-761C-6R-1, 31-33 cm; Figs. 2 and 3) contain identifiable radiolarian faunas, all of which are Cretaceous in age. The other samples (122-761B-14X-3, 117-119 $\mathrm{cm}$; $122-761 \mathrm{~B}-20 \mathrm{X}-1,99-101 \mathrm{~cm} ; 122-761 \mathrm{C}-2 \mathrm{R}-1,126-129 \mathrm{~cm}$; 122-762C-7X-3, 34-36 cm; 122-762C-5X-CC; $122-762 \mathrm{C}-8 \mathrm{X}-3$, $65-67 \mathrm{~cm}$; and $122-762 \mathrm{C}-21 \mathrm{X}-1,118-120 \mathrm{~cm}$ ) contain mostly foraminifers. Many of the radiolarians observed in thin section are partly calcified. Many of the cherty samples are actually silicified mudstones (Pl. 5, Figs. 1-5), whereas the radiolarianproducing samples are cherty (Pl. 5, Fig. 6).

The chert interval in Sample 122-761B-28X-CC, 14-16 cm, contains abundant, small spherules questionably identified as pisolites (PI. 5, Fig. 1). This sample contains upper Lower Cretaceous (upper Albian) radiolarians assignable to the Petasiforma foremanae Zone of Pessagno (1977; equivalent to the upper part of the Acaeniotyle umbilicata Zone of Sanfilippo and Riedel, 1985). Taxa present include Acaeniotyle diaphorogona, Alievium spp., Archaeodictyomitra simplex, Mita gracilis, Thanarla pulchra, Spongocapsula zamoraensis, Stichomitra (?) communis, and Zifondium lassenensis.
The chert interval in Sample 122-761C-5R-2, 147-149 cm, contains a lower Upper Cretaceous (middle to upper Cenomanian) fauna assignable to the Rotaforma hessi Zone of Pessagno (1976; equivalent to the lower part of the Obesacapsula somphedia Zone of Sanfilippo and Riedel, 1985). Agediagnostic taxa include Archaeodictyomitra sliteri, A. (?) turris, Halesium sexangulum, Mita gracilis, Pseudodictyomitra pseudomacrocephala (i.e., large nassellarian illustrated in Pl. 5, Fig. 2), Novixitus mclaughlini, Novixitus spp., Patulibracchium inaequalum, Stichomitra communis, $S$. (?) euganae, $S$. (?) zamoraensis, and Thanarla elegantissima. Silicified foraminifers are abundant (Pl. 5, Fig. 2), and partial calcium carbonate replacement of the radiolarian tests is common (Pl. 5, Fig. 3).

The chert interval in Sample 122-761C-6R-1, 31-33 cm, contains lower Upper Cretaceous (middle Albian) taxa with concurrent ranges near the boundary separating the Kozurium zingulai and Petasiforma foremanae Zones of Pessagno (1977; equivalent to the upper part of the Acaeniotyle umbilicata Zone of Sanfilippo and Riedel, 1985). Diagnostic taxa include Acaeniotyle diaphorogona, A. umbilicata, Acanthocircus dendrocanthus, Archaeodictyomitra squinaboli, Mita magnifica, Pseudodictyomitra carpatica, Xitus spicularius, $X$. spineus, and Zifondium lassenensis. This fauna is the best preserved of all the chert radiolarian faunas; most of the radiolarians are infilled with silica (large nassellarian in Pl. 5, Fig. 5) and not partially replaced by carbonate.

\section{PALEOCENE RADIOLARIAN TAXONOMY}

A short systematic section is included because many of the Leg 122 Paleocene taxa have had little or no systematic treatment. Only genera and species are discussed, listed in alphabetical order. The brief synonomies include only the origin of the specific names.

Genus AMPHISPHAERA Haeckel, 1881

Amphisphaera minor (Clark and Campbell)

(Pl. 3, Fig. 23)

Stylosphaera minor Clark and Campbell, 1942, p. 27, pl. 5, figs. 1, 2, 12.

Amphisphaera minor (Campbell and Clark) in Sanfilippo and Riedel, 1973, p. 486 , pl. 1 , figs. $1-5$; pl. 22 , fig. 4.

Genus AMPHIPTERNIS Foreman, 1973

Amphipternis sp. cf. ?Stichomitra alamedaensis (Campbell and Clark)

(Pl. 2, Fig. 5)

cf. Phormocampe (Cyrtocorys) alamedaensis Campbell and Clark, 1944b, p. 37, pl. 7, fig. 41 .

cf. Phormocampe (Cyrtocorys) alamedaensis var. tenuis Campbell and Clark, 1944b, p. 37, pl. 7, figs. 35-36.

cf. ?Stichomitra alamedaensis (Campbell and Clark) in Foreman, 1968 , p. 77 , pl. 8 , fig. 4

Amphipternis sp. cf. ?Stichomitra alamedaensis (Campbell and Clark) in Foreman, 1973, p. 430, pl. 7, fig. 18; pl. 9, fig. 1.

Genus AMPHYMENIUM Haeckel, 1881

Amphymenium splendiarmatum Campbell and Clark

$$
\text { (Pl. 2, Fig. 10) }
$$

Amphymenium splendiarmatum Campbell and Clark, 1942, p. 46, pl. 1, figs. 12, 14. Sanfilippo and Riedel, 1973, p. 524, pl. 11, figs. 6-8; pl. 28 , figs. $6-8$.

Remarks. All of the Leg 122 two-armed spongdiscids possess chambered arms with spongy terminations that are conical or flatly expanded.

\section{ASTROSPHAERINS}

(cf. Sanfilippo and Riedel, 1973)

Remarks. According to Foreman (1973), little is known about astrosphaerins and whether they should be included as a subfamily of the Actinommidae Haeckel (in the sense of Riedel, 1967). 
Astrosphaerin sp. E

(Pl. 4, Fig. 11)

Sanfilippo and Riedel, 1973, p. 488, pl. 6, figs. 3-6; pl. 23, fig. 1.

Remarks. Astrosphaerin sp. E differs from sp. F by having two curved and one straight projections.

\section{Astrosphaerin sp. F \\ (PI. 4, Fig. 12)}

Sanfilippo and Riedel, 1973, p. 488, pl. 6, figs. 7-8; pl. 23, fig. 2.

Genus BATHROPYRAMIS Haeckel, 1881

Bathropyramis (Acropyramis) sp. cf. B. woodringi Campbell and

Clark, 1944a

(Pl. 4, Fig. 6)

Bathropyramis (Acropyramis) woodringi Campbell and Clark, 1944a, p. 39 , pl. 5 , figs. $21-22$.

Remarks. This form differs from $B$. woodringi by having a larger number and thinner radial beams with offsetting horizontal bars.

\section{Genus BEKOMA Riedel and Sanfilippo, 1971 Bekoma campechensis Foreman \\ (Pl. 4, Figs. 15, 17)}

Foreman, 1973, p. 432 , pl. 3, fig. 24 ; pl. 10, figs. 1-2; p. 444, fig. 4 .

Bekoma sp. aff. B. campechensis Foreman

(Pl. 4, Fig. 7)

Remarks. Bekoma sp. aff. B. campechensis differs from $B$. campechensis by having shorter, less robust, and slightly curved feet.

Bekoma divaricata Foreman

(Pl. 4, Fig. 13)

Foreman, 1973, p. 433, pl. 3, fig. 23; pl. 10, figs. 3-4.

Genus BURYELLA Foreman, 1973

Buryella sp. cf. B. clinata Foreman

(PI. 1, Fig. 3)

Buryella clinata Foreman, 1973, p. 433, pl. 8, figs. 1-3; pl. 9, fig. 19.

Buryella pentadica Foreman

(Pl. 3, Figs. 4, 5)

Foreman, 1973, p. 433, pl. 8, fig. 8; pl. 9, figs. 15-16.

\section{Buryella tetradica Foreman}

(PI. 1, Figs. 7, 8)

Foreman, 1973, p. 433, pl. 8, figs. 4-5; pl. 9, figs. 13-14.

Remarks. This species has been found in Paleocene and lower Eocene assemblages from tropical localities in all three major oceans (Sanfilippo et al., 1985).

\section{Buryella sp. A}

(Pl. 1, Figs. 1, 2)

Remarks. Buryella sp. A differs from others species of Buryella in this report by possessing a less curved test and a prominent cephalis.

\section{Genus CERATOSPYRIS Ehrenberg, 1847 \\ Ceratospyris sp. aff. $C$. articulata Ehrenberg}

(Pl. 2, Figs. 12, 13)

Ceratospyris articulata Ehrenberg, 1873, p. 218, pl. 20, fig. 4 .

\section{Genus CLATHROCYCLOMA Haeckel, 1887 \\ Clathrocycloma parcum Foreman}

(Pl. 4, Figs. 1, 2)

Foreman, 1973, pp. 434-435, pl. 2, fig. 13; pl. 11, fig. 12.

Clathrocycloma sp. A

(P1. 2, Fig. 18)

Clathrocycloma spp., Foreman, 1973, pl. 2, fig. 12.

Remarks. This form differs from $C$. parcum by possessing a broad skirt and finer pore frames.
Genus CORNUTELLA Ehrenberg, 1838, emend. Nigrini, 1967 Cornutella californica Campbell and Clark, emend. Foreman, 1968 (Pl. 3, Figs. 13, 24)

Campbell and Clark, 1944b, pp. 22-23, pl. 7, figs. 33-34, 42-43; emend. Foreman, 1968, pp. 21-22, pl. 3, figs. 1a-1c.

\section{Genus DICTYOCERAS Haeckel, 1862 \\ Dictyoceras caia Foreman}

(PI. 3, Fig. 12)

Foreman, 1973, p. 435, pl. 2, fig. 7; pl. 9, fig. 21.

\section{Genus DICTYOMITRA Zittel, 1876}

Dictyomitra andersoni (Campbell and Clark), emend. Foreman, 1968

(Pl. 1, Fig. 12)

Lithocampe (Lithocampanula) andersoni Campbell and Clark, 1944b, p. 42 , pl. 8 , fig. 25 .

Dictyomitra (Dictyomitroma) multicostata Zittel in Campbell and Clark, 1944b, p. 39, pl. 8, figs. 22-24, 29, 35.

Lithomitra (Lithomitrissa) regina var. subconica Campbell and Clark, 1944b, p. 41, pl. 8, fig. 28.

Dictyomitra (Dictyomitroma) tiara Campbell and Clark, 1944b, p. 40, pl. 8, figs. 1-4, 12 .

Dictyomitra andersoni (Campbell and Clark) in Foreman, 1968, p. 68, pl. 7, figs. $6 \mathrm{a}-6 \mathrm{~d}$.

Genus DORCADOSPYRIS Haeckel, 1881

Dorcadospyris $\mathrm{sp}$. cf. D. platyacantha (Ehrenberg)

(Pl. 2, Figs. 2-4)

Petalospyris platyacantha Ehrenberg, 1873, p. 247; 1875, pl. 22, fig. 8 . Dorcadospyris confluens (Ehrenberg) in Goll, 1969, p. 337, pl. 58, figs. 9-12.

Dorcadospyris platyacantha (Ehrenberg) in Sanfilippo and Riedel, 1973, p. 528, pl. 17, figs. 11-15; pl. 33, fig. 2 .

Remarks. These forms differ from D. platyacantha by possessing more divergent and less flattened feet.

\section{Dorcadospyris sp. A}

(PI. 1, Figs. 9, 10)

Remarks. This form differs from $D$. platyacantha by lacking an apical spine and possessing a smaller, thinner sagittal ring with thinner sagittal spines.

\section{Dorcadospyris sp. B}

(Pl. 2, Fig. 19)

Remarks. This form differs from $D$. platyacantha by having a larger inflated cephalis.

\section{Genus ENTAPIUM Sanfilippo and Riedel, 1973 \\ Entapium chaenapium Sanfilippo and Riedel}

$$
\text { (PI. 4, Fig. 5) }
$$

Sanfilippo and Riedel, 1973, pp. 491-492, pl. 1, fig. 3; pl. 23, figs. 9-12.

Entapium regulare Sanfilippo and Riedel

(PI. 3, Fig. 20)

Sanfilippo and Riedel, 1973, p. 492, pl. 2, figs. 10-19; pl. 24, figs. 1-3.

$$
\text { Entapium sp. A }
$$

(Pl. 3, Fig. 22)

Remarks. This undescribed form differs from E. regulare Sanfilippo and Riedel in possessing a smaller cortical shell with longer, more massive bladed spines and differs from $E$. chaenapium Sanfilippo and Riedel by having six or more bladed primary spines.

\section{Genus HELIOSTYLUS Haeckel, 1881 Heliostylus sp. \\ (Pl. 4, Fig. 10)}

Heliostylus spp. in Sanfilippo and Riedel, 1973, p. 522, pl. 8, figs. 1-2; pl. 27 , fig. 1 . 
Remarks. Sanfilippo and Riedel (1973) applied this generic name to all phacodiscids in which two opposite bars connect the cortical and outer medullary shells.

\section{Genus LITHOCHYTRIS Ehrenberg, 1847 ? Lithochytris sp. A \\ (Pl. 3, Figs. 8, 9)}

Remarks. This form differs from other taxa belonging to this genus (cf. Foreman, 1973, p. 436) by having thinner walls with larger pores and spines projecting from the large thorax vs. the abdomen.

\section{Genus LITHOMESPILUS Haeckel, 1881 \\ Lithomespilus mendosa (Krasheninnikov)}

(Pl. 2, Figs. 16, 17)

Ellipsidium (?) mendosum Krasheninnikov, 1960, p. 281, pl. 1, fig. 14. Ellipsidium cultum Borisenko, 1960, p. 224, pl. 3, fig. 4.

Lithomespilus mendosa (Krasheninnikov) in Riedel and Sanfilippo, 1973 , pp. $517-518$, pl. 4 , figs. $6-7$; pl. 24 , figs. $10-11$.

\section{Genus LITHOMITRA Bütschli, 1882 \\ Lithomitra docilis Foreman}

(Pl. 1, Fig. 4)

Foreman, 1973, p. 431, pl. 8, figs. 20-22; pl. 9, figs. 3-5.

Remarks. This taxon first appears in the lowermost Paleocene and ranges into the lower Oligocene. It also differs from forms placed by Nigrini (1977) into the Siphocampe lineata group in possessing an upward-directed tube and differently arranged pores.

\section{Genus LYCHNOCANOMA Haeckel, 1887 \\ Lychnocanoma sp. A}

(Pl. 3, Figs. 1, 17)

Lamptonium pennatum Foreman in Sanfilippo and Riedel, 1979, p. 504, pl. 1, figs. 3-4.

Remarks. This form is similar to the forms assigned to $L$. pennatum by Sanfilippo and Riedel (1979) but differs in possessing a less rounded thorax.

\section{Lychnocanoma sp. B \\ (PI. 2, Figs. 7, 11)}

Remarks. This distinct form differs from sp. A by possessing a tapering thorax and an incomplete abdomen with a ragged termination. It also has more slender feet.

\section{Lychnocanoma sp. C \\ (Pl. 3, Figs. 11, 16)}

Remarks. This form differs from the species of Lychnocanoma discussed previously by possessing a large, bladed horn and long bladed feet.

\section{Lychnocanoma sp. D}

(Pl. 3, Figs. 14, 21)

Lychnocanoma sp. in Westberg et al., 1980, pl. 1, fig. 12.

Remarks. This form differs from $L$. anacolum, L. auxilla, and other species of Lychnocanoma by possessing a small horn and an inflated thorax.

\section{Lychnocanoma sp. E}

$$
\text { (Pl. 3, Fig. 15) }
$$

?Dictyophimus spp. in Dumitrică, 1973, p. 788, pl. 7, figs. 5-6, 8-9.

Remarks. This form differs from sp. D by having feet that radiate out from the test at a relatively high angle and a long, tubular third segment.

\section{?Lychnocanoma sp. F}

(Pl. 2, Fig. 1)

Remarks. This form is questionably assigned to Lychnocanoma because it lacks a definable third segment. It also differs from sp. A and sp. B by possessing a larger cephalis and curved feet.

\section{Genus PERIPHAENA Ehrenberg, 1873 \\ Periphaena decora Ehrenberg}

(PI. 4, Fig. 14)

Periphaena decora Ehrenberg, 1873, p. $246 ; 1875$, pl. 28 , fig. 6 Riedel, 1957, p. 258, pl. 62, fig. 1. Sanfilippo and Riedel, 1973, p. 523 , pl. 8 , figs. $8-10 ;$ pl. 27 , figs. $2-5$.
Haliomma humboldti Ehrenberg, 1854, pl. 36, fig. 27; 1875, pl. 27, fig. 3. Heliodiscus humboldti (Ehrenberg) in Haeckel, 1887, p. 449. Riedel, 1957 , p. 258 , pl. 62 , fig. 2 .

Heliodiscus cingillum Haeckel, 1887, p. 448, pl. 33, fig. 7.

Periphaena cincta Haeckel, 1887, p. 426, pl. 33, fig. 4.

Perizona scutella Haeckel, 1887, p. 427, pl. 32, fig. 7.

Remarks. This species differs from Periphaena heliasteriscus (Clark and Campbell) by having a girdle of varying width (Leg 122 forms have a narrow girdle), with or without spines.

\section{Genus PHORMOCYRTIS Haeckel, 1887 \\ Phormocyrtis striata exquisita (Kozlova)}

$$
\text { (Pl. 3, Figs. 6, 7) }
$$

Pododcyrtis exquisita Kozlova in Kozlova and Gorbovets, 1966, p. 106, pl. 17, fig. 2 .

Phormocyrtis striata Brandt in Riedel and Sanfilippo, 1971, pl. 8, fig. 4. Phormocyrtis striata exquisita (Kozlova) in Foreman, 1973, p. 438, pl. 7 , figs. $1-4,7-8$; pl. 12 , fig. 5 .

\section{Phormocyrtis striata striata Brandt}

$$
\text { (Pl. 2, Fig. 6) }
$$

Phormocyrtis striata Brandt in Wetzel, 1935, p. 55, pl. 9, fig. 12. Riedel and Sanfilippo, 1970, p. 532, pl. 10, fig. 7.

Phormocyrtis striata striata Brandt in Foreman, 1973, p. 438, pl. 7, figs. 5-6, 9 .

$$
\begin{gathered}
\text { Genus PTEROCODON Ehrenberg, } 1847 \\
\text { Pterocodon (?) ampla (Brandt) }
\end{gathered}
$$

$$
\text { (Pl. 2, Figs. 14, 15) }
$$

?Theocyrtis ampla Brandt in Wetzel, 1935, p. 56, pl. 9, figs. 13-15.

?Theocorys unicum Lipman in Lipman et al., 1960, p. 97, pl. 12, fig.

11. Kozlova in Kozlova and Gorbovets, 1966, p. 109, pl. 17, fig. 5.

Pterocodon (?) ampla (Brandt) in Foreman, 1973, pp. 438-439, pl. 5, figs. 3-5.

Remarks. There is considerable variation in test wall thickness, shape of the apical spine and thorax, and arrangement of pores in both the Leg 122 morphotypes and those illustrated by Foreman (1973).

This species ranges across the Paleocene/Eocene boundary and has been recovered from northern Europe, the tropical Pacific, Gulf of Mexico, and the Caribbean (Sanfilippo et al., 1985).

Genus SATURNULUS Haeckel, 1881, emend. Nigrini, 1967 Saturnulus sp. A

$$
\text { (Pl. 4, Fig. 9) }
$$

?Saturnulus sp. cf. planetes Haeckel in Dumitrică, 1973, p. 787, pl. 1, fig. 8.

Genus SIPHOCAMPE Haeckel, 1881, emend. Nigrini, 1977 Siphocampe sp. aff. S. arachnea (Ehrenberg) group

$$
\text { (Pl. 1, Figs. 5, 6) }
$$

Lithocampe lineata Ehrenberg, 1838, p. 130.

Eucyrtidium lineata (Ehrenberg) in Ehrenberg, 1854, pl. 22, fig. 26; pl. 36 , fig. $16 \mathrm{C}$

Lithomitra lineata (Ehrenberg) group Riedel and Sanfilippo, 1971, p. 1600 , pl. 11, figs. $1-11$; pl. 21, figs. 14-16; pl. 3E, fig. 14. Foreman, 1973, p. 431, pl. 8, fig. 19.

Siphocampe arachnea (Ehrenberg) group Nigrini, 1977, p. 255, pl. 3, figs. 7-8.

Remarks. The Leg 122 forms differ from $S$. arachnea by possessing post-thoracic segmentations with more pronounced constrictions both proximally and distally between pore rows. The morphotype illustrated by Foreman (1973) as belonging to the Lithomitra lineata (Ehrenberg) group is similar to forms figured in this report.

$$
\begin{gathered}
\text { Genus SPONGODISCUS Ehrenberg, } 1854 \\
\text { Spongodiscus sp. A } \\
\text { (PI. 4, Fig. 16) }
\end{gathered}
$$

Spongodiscus sp. in Sanfilippo and Riedel, 1973, pl. 11, figs. 18-19.

\section{Genus SPONGURUS Haeckel, 1887}

Spongurus (Spongurantha) quadratus Campbell and Clark

$$
\text { (Pl. 3, Fig. 19) }
$$

Campbell and Clark, 1944b, p. 13, pl. 5, fig. 9.

Spongurus spp. in Dumitrică, 1973, p. 788, pl. 5, figs. 1-3. 
Remarks. This species, illustrated in a line drawing in Campbell and Clark (1944b), is similar to the Leg 122 forms.

Genus STYLOSPHAERA Ehrenberg, 1847

Stylosphaera coronata coronata Ehrenberg

(Pl. 1, Figs. 11, 15)

Stylosphaera coronata Ehrenberg, 1873, p. 258; 1875, pl. 25, fig. 4.

Druppatractus trichopterus Clark and Campbell, 1942, p. 34, pl. 5, fig. 4.

?Lothatractus hederae Clark and Campbell, 1942, p. 33, pl. 5, fig. 3. ?Druppatractus polycentrus Clark and Campbell, 1942, p. 35 , pl. 5 , fig. 19.

?Druppatractus parasagittatus Middour in Frizzell and Middour, 1951 , p. 21 , pl. 2, figs. 11-12.

Stylosphaera coronata coronata Ehrenberg in Sanfilippo and Riedel, 1973, p. 520, pl. 1, figs. 13-17; pl. 25, fig. 4 .

Stylosphaera goruna Sanfilippo and Riedel

(Pl. 1, Figs. 17-20)

Sanfilippo and Riedel, 1973, p. 521, pl. 1, fig. 19; pl. 25, figs. 5-6.

Stylosphaera sp. A

(Pl. 1, Figs. 13, 14)

Remarks. This form differs from $S$. coronata coronata by possessing shorter three-bladed spines of equal or nearly equal length.

\section{Stylosphaera sp. B}

(PI. 1, Fig. 16)

Remarks. This form differs from species of Stylosphaera discussed previously by possessing two long-bladed spines of equal or nearly equal length.

Genus STYLOTROCHUS Haeckel, 1862

Stylotrochus alveatus Sanfilippo and Riedel (Pl. 4, Fig. 8)

Sanfilippo and Riedel, 1973, p. 525, pl. 13, figs. 4-5; pl. 30, figs. 3-4.

Stylotrochus nitidus Sanfilippo and Riedel

(Pl. 3, Fig. 10)

Sanfilippo and Riedel, 1973, p. 525, pl. 13, figs. 9-14; pl. 30, figs. 7-10.

Genus THEOCORYS Haeckel, 1881

Theocorys phyzella Foreman

(Pl. 2, Figs. 8, 9)

Foreman, 1973, p. 440, pl. 5, fig. 8; pl. 12, fig. 1.

Theocorys sp. cf. T. phyzella Foreman

(PI. 3, Figs. 2, 3)

Remarks. This form differs from $T$. phyzella by having a greater stricture between the cephalis and abdomen and a more inflated abdomen.

\section{Genus THECOSPHAERELLA Haeckel, 1887}

Thecosphaerella ptomatus Sanfilippo and Riedel (PI. 3, Fig. 18)

Sanfilippo and Riedel, 1973, pp. 521-522, pl. 3, figs. 14-18; pl. 26, fig. 2.

Genus VELICUCULLUS Riedel and Campbell, 1952

Velicucullus sp.

(Pl. 4, Fig. 3)

Velicucullus sp. in Sanfilippo and Riedel, 1973, p. 530, pl. 20, fig. 5.

Genus XIPHOSPIRA Haeckel, 1887

Xiphospira circularis (Clark and Campbell)

(PI. 4, Fig. 4)

Porodiscus circularis Clark and Campbell, 1942, p. 42, pl. 2, figs. 2, 6, 10.

Xiphodictya amphixiphos Clark and Campbell, 1942, p. 43, pl. 2, fig. 4.

Xiphospira circularis (Clark and Campbell) 1942 in Sanfilippo and Riedel, 1973, p. 526, pl. 14, figs. 5-12; pl. 31, figs. 4-7.

\section{REFERENCES}

Aita, Y., 1987. Middle Jurassic to Lower Cretaceous radiolarian biostratigraphy of Shikoku with reference to selected sections in Lombardy Basin and Sicily. Sci. Rep. Tohoku Univ., Ser. 2, 1-58.

Baumgartner, P. O., 1984. A Middle Jurassic-Early Cretaceous low-latitude radiolarian zonation based on unitary associations and age of Tethyan radiolarites. Eclogae Geol. Helv. 77:729-837.

Blome, C. D., 1984. Upper Triassic radiolarians and radiolarian zonation for western North America. Bull. Am. Paleontol., 84:188.

Borisenko, N. N., 1958. Radiolyarii paleotsena zapadnoi Kubani. Tr. Vses. Neft. Nauchno-Issled. Inst., Krasnodarskii Filial, 17:81100.

1960. Novye radiolyarii iz paleotsenovykh otlozhenii Kubani. Tr. Vses. Neft. Nauchno-Issled. Inst., Krasnodarskii Filial, 4:199-207.

Bütschli, O., 1882. Beitrage zur Kentniss der Radiolarienskelette, insbesondere der Cyrtida. Z. Wiss. Zool., 36:485-540.

Campbell, A. S., and Clark, B. L., 1944a. Miocene radiolarian faunas from southern California. Spec. Pap.-Geol. Soc. Am., 51:1-76.

, 1944b. Radiolaria from Upper Cretaceous of middle California. Spec. Pap.-Geol. Soc. Am., 57:1-61.

Clark, B. L., and Campbell, A. S., 1942. Eocene radiolarian faunas from the Mt. Diablo area, California. Spec. Pap.-Geol. Soc. Am., 39:1-112.

1945. Radiolaria from the Kreyenhagen Formation near Los Banos, California. Mem. Geol. Soc. Am., 10:1-66.

Dumitricå, P., 1973. Paleocene radiolaria, DSDP Leg 21. In Burns, R. E., Andrews, J. E., et al., Init. Repts. DSDP, 21: Washington (U.S. Govt. Printing Office), 787-817.

Ehrenberg, C. G., 1838. Uber die Bildung der Kreidefelsen und des Kreidemergels durch unsichtbare Organismen. Abh. K. Akad. Wiss. Berlin, 59-147.

1847. Uber eine halibiolithische, von Herrn R. Schomburgk entdeckte, vorherrschend aus mikroskopischen Polycystinen gebildete, Gebirgsmasse von Barbados. K. Preuss. Akad. Wiss. Berlin, Monatsbericht, Jahre 1846:382-385.

1854. Die systematiche Charakteristik der neuen mikroskopischen Organismen des tiefen Atlantischen Oceans. K. Preuss. Akad. Wiss. Berlin, Bericht, Jahre 1854:236-250.

1873. Grössere Felsproben des Polycystinen-Mergels von Barbados mit weiteren Erlaüterungen. K. Preuss. Akad. Wiss. Berlin, Monatsberichte, 213-263.

1875. Fortsetzung der mikrogeologischen Studien als Gesammt-Uebersicht der mikroskopischen Paläontologie gleichartig analysirter Gebirgsarten der Erde, mit specieller Rücksicht auf den Polycystinen-Mergel von Barbados. Abh. K. Akad. Wiss. Berlin, 1-225.

Exon, N. F., von Rad, U., and von Stackelberg, U., 1982. The geological development of the passive margins of the Exmouth Plateau off northwest Australia. Mar. Geol., 47:131-152.

Foreman, H. P., 1968. Upper Maestrichtian Radiolaria of California. Spec. Pap., Palaeontol. Assoc. London, 3:1-82.

1973. Radiolaria of Leg 10 with systematics and ranges for the families Amphipyndacidae, Artostrobiidae, and Theoperidae. In Worzel, J. L., Bryant, W., et al., Init. Repts. DSDP, 10: Washington (U.S. Govt. Printing Office), 407-474.

Frizzell, D. L., and Middour, E. S., 1951. Paleocene Radiolaria from southeastern Missouri. Univ. Missouri, Sch. Mines Metall. Bull., Tech. Ser., 77:1-41.

Goll, R. M., 1969. Classification and phylogeny of Cenozoic Trissocyclidae (Radiolaria) in the Pacific and Caribbean basins. Part II. J. Paleontol., 43:322-339.

Haeckel, E., 1862. Die Radiolarien (Rhizopoda Radiaria): Berlin (Reimer).

1881. Entwurf eines Radiolarien-Systems auf Grund von studien der Challenger-Radiolarien (Basis for a radiolarian classification from the study of Radiolaria of the Challenger collection). Jena. Z. Med. Naturwiss., 15:418-472.

1887. Report on the Radiolaria collected by H.M.S. Challenger during the years 1873-1876. Rep. Sci. Results Voy. H.M.S. Challenger, Zool., 18:1-1803. 
Haq, B. U., Hardenbol, J., and Vail, P. R., 1987. Chronology of fluctuating sea levels since the Triassic. Science, 235:1156-1167.

1988. Mesozoic and Cenozoic chronostratigraphy and cycles of sea-level change. In Wilgus, C. K., Hastings, B. S., Kendall, C.G.St.C., Posamentier, H. W., Ross, C. A., and Van Wagoner, J. C. (Eds.), Sea-Level Changes-An Integrated Approach. Spec. Publ.-Soc. Econ. Paleontol. Mineral., 42:71-108.

Haq, B. U., von Rad, U., O'Connell, S., et al., 1990. Proc. ODP, Init. Repts., 122: College Station, TX (Ocean Drilling Program).

Kozlova, G. E., and Gorbovets, A. N., 1966. Radiolyarii verkhnemelovykh i verkhneeotsenovykh otlozhenii Zapadno-Sibirskoi Nizmennosti [Radiolaria of the Upper Cretaceous and upper Eocene of the west Siberian Lowland]. Tr. Vses. Neft. NauchnoIssled. Geologorazved. Inst., 248:1-159.

Krasheninnikov, V. A., 1960. Nektorye Radiolyarii Nizhnego i Srednego Eotsena Zapadnogo Predkavkazya. Min. Geol. Okhr. Nedr. SSSR, Vses. Nauchno-Issled. Geol. Neft. Inst., 16:1-271.

Lipman, R. K., 1972. Paleogenovye Radiolyarii SSSR. [Dissert.] Ministerstvo Vysshego i Srednego Spetsialnogo Obrazovaniya Rsfsr Leningradskii Ordeno Lenina i Ordena Trudovogo Krasnogo Znameni Gornyi Institut G. B. Plekhanova Dissertatsii na soiskanie uchenoi stepeni Doktora Geologo-Mineralogicheskikh Nauk, Leningrad.

Lipman, R. K., Burtman, E. S., and Khokhlova, I. A., 1960. Stratigraphy and fauna of the Paleogene deposits in the western Siberian Lowland. Min. Geol. Okhr. Nedr. SSSR, Tr. Vses. Nauchno-Issled. Geol. Inst., new ser., 28:69-98, 154-172.

Martini, E., 1971. Standard Tertiary and Quaternary calcareous nannoplankton zonation. In Farinacci, A. (Ed.), Proc. 2nd Planktonic Conf. Roma: Rome (Ed. Technosci.), 2:739-785.

Nigrini, C., 1967. Radiolaria in pelagic sediments from the Indian and Atlantic Oceans. Bull. Scripps Inst. Oceanogr., 11:1-125.

1977. Tropical Cenozoic Artostrobiidae (Radiolaria). Micropaleontology, 23:241-269.

Nishimura, A., 1987. Cenozoic Radiolaria in the western North Atlantic, Site 603, Leg 93 of the Deep Sea Drilling Project. In Blakeslee, J. H., and Whalen, E., Init. Repts. DSDP, 93 (Pt. 2): Washington (U.S. Govt. Printing Office), 713-738.

1988. Paleocene radiolarian biostratigraphy at DSDP 384 , northwest Atlantic. Geol. Palaeontol. (Marburg), 22:201. (Abstract)

Pessagno, E. A., Jr., 1976. Radiolarian zonation and stratigraphy of the Upper Cretaceous portion of the Great Valley Sequence, California Coast Ranges. Micropaleontology, Spec. Publ., 2:1-95. 1977. Lower Cretaceous radiolarian biostratigraphy of the Great Valley Sequence and Franciscan Complex, California Coast Ranges. Spec. Publ. Cushman Found. Foraminiferal Res., 15:187.

Pessagno, E. A., Jr., and Newport, R. L., 1972. A technique for extracting Radiolaria from radiolarian cherts. Micropaleontology, 18:231-234.

Riedel, W. R., 1957. Geology of Saipan, Mariana Islands. Part 3. Paleontology. Eocene Radiolaria. Geol. Surv. Prof. Pap. U.S., 280G:257.

1967. Subclass Radiolaria. In Harland, W. B., Holland, C. H., House, M. R., Hughes, N. F., Reynolds, A. B., Rudwick, M.J.S., Satterthwaite, G. E., Tarlo, L.B.H., and Willey, E. C. (Eds.), The Fossil Record. Geol. Soc. London, 291-298.

Riedel, W. R., and Campbell, A. S., 1952. A new Eocene radiolarian genus. J. Paleontol., 26:667-669.
Riedel, W. R., and Sanfilippo, A., 1970. Radiolaria, Leg 4, Deep Sea Drilling Project. In Bader, R. G., Gerard, R. D., et al., Init. Repts. DSDP, 4: Washington (U.S. Govt. Printing Office), 503-575. 1971. Cenozoic radiolaria from the western tropical Pacific, Leg 7. In Winterer, E. L., Riedel, W. R., et al., Init. Repts. DSDP, 7 (Pt. 2): Washington (U.S. Govt. Printing Office), 1529-1672. 1978. Stratigraphy and evolution of tropical Cenozoic radiolarians. Micropaleontology, 23:61-96.

Sanfilippo, A., and Riedel, W. R., 1973. Cenozoic Radiolaria (exclusive of theoperids, artostrobids and amphipyndacids) from the Gulf of Mexico, Deep Sea Drilling Project Leg 10. In Worzel, J. L., Bryant, W., et al., Init. Repts. DSDP, 10: Washington (U.S. Govt. Printing Office), 475-611.

1976. Radiolarian occurrences in the Caribbean Region. Publication de la VII Conférence Géologique des Caraibes du 20 Juin au 12 Juillet 1974. VII Conf. Géol. des Caraibes, Cayenne, Dep. Français de la Guyana, 145-168.

1979. Radiolaria from the northeastern Atlantic Ocean, DSDP Leg 48. In Montadert, L., Roberts, D. G., et al., Init. Repts. DSDP, 48: Washington (U.S. Govt. Printing Office), 493-511.

1985. Cretaceous Radiolaria. In Bolli, H. M., Saunders, J. B., and Perch-Nielsen, K. (Eds.), Plankton Stratigraphy: Cambridge (Cambridge Univ. Press), 573-630.

Sanfilippo, A., Westberg-Smith, M. J., and Riedel, W. R., 1985. Cenozoic Radiolaria. In Bolli, H. M., Saunders, J. B., and Perch-Nielsen, K. (Eds.), Plankton Stratigraphy: Cambridge (Cambridge Univ. Press), 631-712.

Schaaf, A., 1981. Late Early Cretaceous radiolarian from Deep Sea Drilling Project Leg 62. In Thiede, J., Vallier, T. L., et al., Init. Repts. DSDP, 62: Washington (U.S. Govt. Printing Office), 419-470. 1984. Les radiolaires du Crétacé infériuer et moyen: biologie et systématiques. Sci. Geol. Mem., 75:1-189.

Shipboard Scientific Party, 1990. Site 761. In Haq, B. U., von Rad, U., et al., Proc. ODP, Init. Repts., 122: College Station, TX (Ocean Drilling Program), 161-211.

Taketani, Y., 1982. Cretaceous radiolarian biostratigraphy of the Urakawa and Obira areas, Hokkaido. Sci. Rep. Tohoku Univ. Ser. 2, 1-52.

Tochilina, S. V., 1975. Biostratigraficheskaya kharakteristika paleotseneotsenovykh otlozhenii Voronezhskoi anteklizy. Tr. Vses. Ordena Nauchno-Issled. Geol. Inst. (VSEGEI), new ser., 226:78-84.

Westberg, M. J., Sanfilippo, A., and Riedel, W. R., 1980. Radiolarians from the Moroccan Basin, DSDP, Leg 50. In Lancelot, Y., Winterer, E. L., et al., Init. Repts. DSDP, 50: Washington (U.S. Govt. Printing Office), 429-434.

Wetzel, O., 1935. Die mikropalaeontologie des Heiligenhafener Kieseltones (Ober-Eözan). Niedersaechs. Geol. Verein, Jahresbericht, 27:41-81.

Yamasaki, T., 1987. Radiolarian assemblages of the Izumi Group in Shikoku and western Awayi Island, southwest Japan. Chishitsugaku Zasshi, 93:403-417.

Zittel, K. A., 1876. Uber einige fossile Radiolarien auf der norddeutschen Kreide. Zeitschr. Dtsch. Geol. Gesell., 28:75-86.

Date of initial receipt: 4 June 1990

Date of acceptance: 18 December 1990

Ms 122B-165 


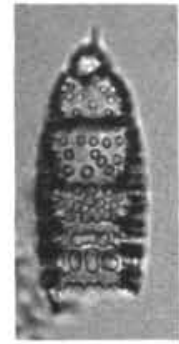

1

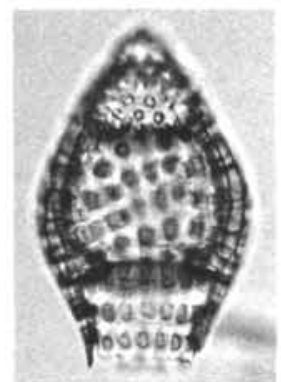

7

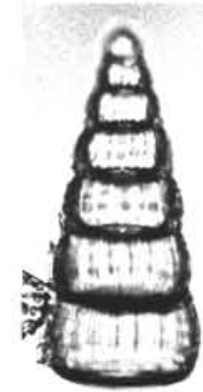

12

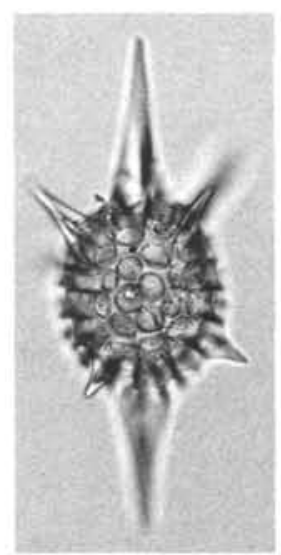

17

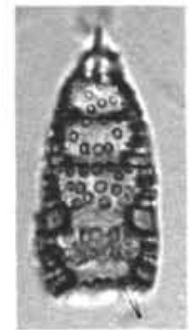

2

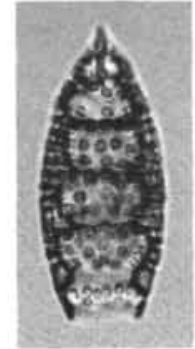

3

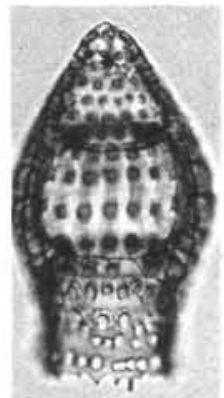

8

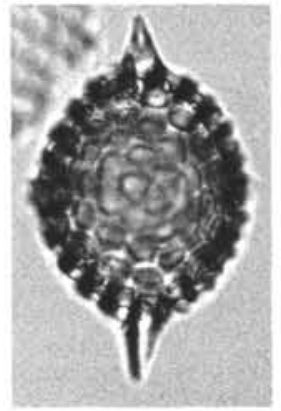

13

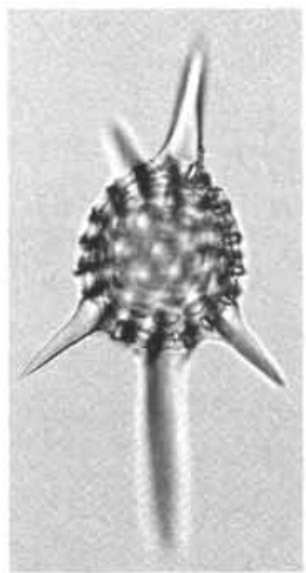

18

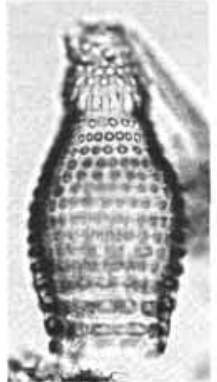

4

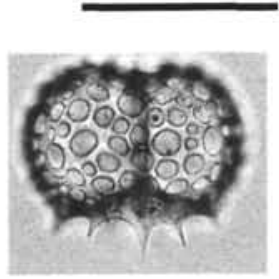

9

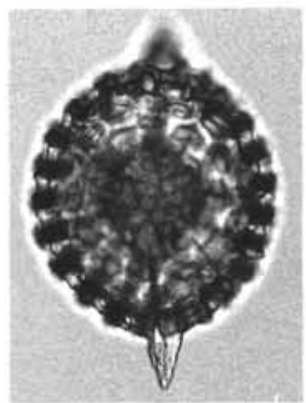

14
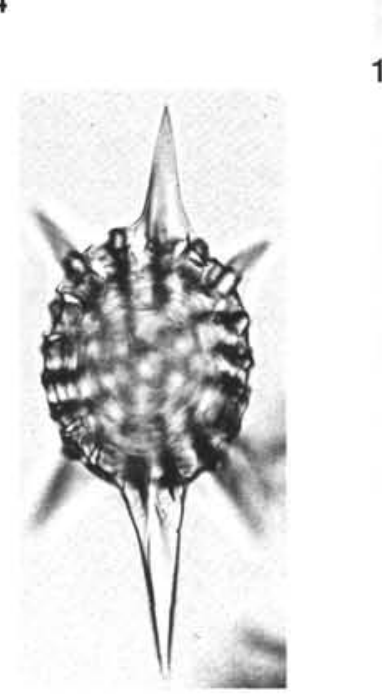

19

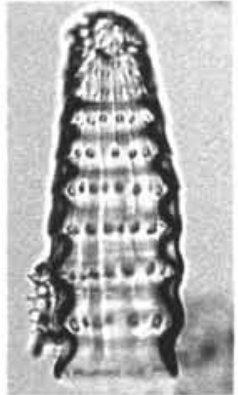

5

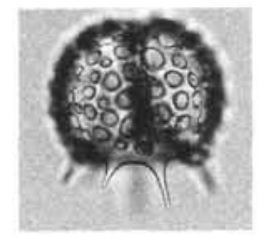

10

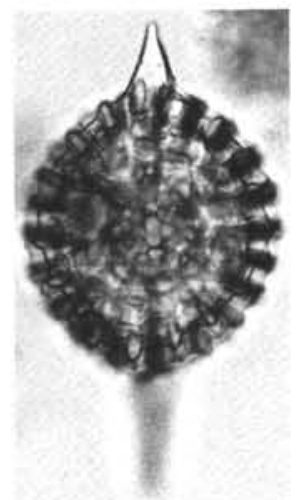

15

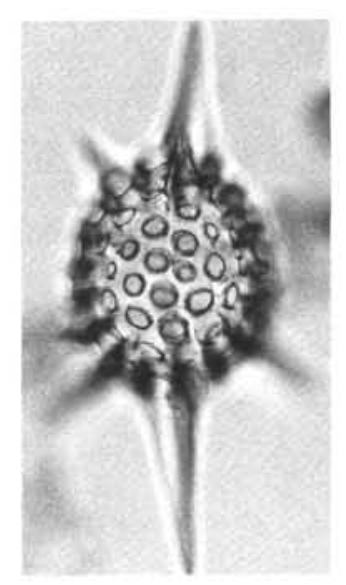

20

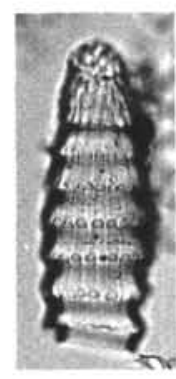

6

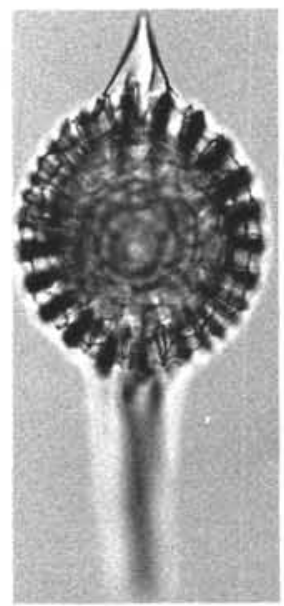

11

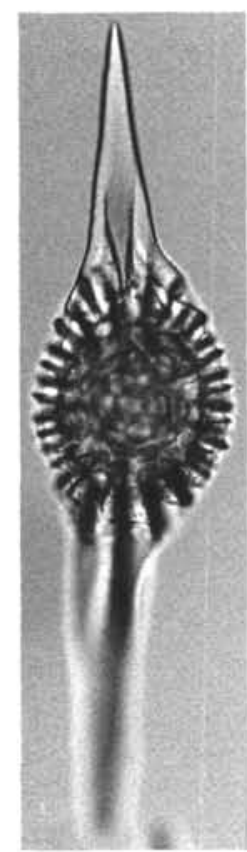

16

Plate 1. Scale bar $=80 \mu \mathrm{m} .1$, 2. Buryella sp. A; Sample 122-761B-17X-4, 67-69 cm. 3. Buryella sp. cf. B. clinata; Sample 122-761B-17X-3, 67-69 $\mathrm{cm}$. 4. Lithomitra docilis; Sample 122-761B-17X-1, 133-136 cm. 5, 6. Siphocampe sp. aff. S. arachnea; (5) Sample 122-761B-18X-4, 67-69 cm, (6) Sample 122-761B-17X-3, 133-136 cm. 7, 8. Buryella tetradica; Section 122-761B-16X-CC. 9, 10. Dorcadospyris sp. A; Sample 122-761B$17 \mathrm{X}-3,67-69 \mathrm{~cm}$. 11, 15. Stylosphaera coronata coronata; Sample 122-761B-17X-1, 133-136 cm. 12. Dictyomitra andersoni; Sample 122-761B-18X-1, 67-69 cm. 13, 14. Stylosphaera sp. A; Sample 122-761B-17X-5, 67-69 cm. 16. Stylosphaera sp. B; Sample 122-761B-18X-2, 67-69 cm. 17-20. Stylosphaera goruna; (17-19) Section 122-761B-16X-CC, (20) Sample 122-761B-17X-3, 133-136 cm. 


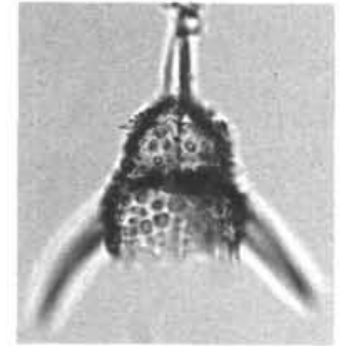

1

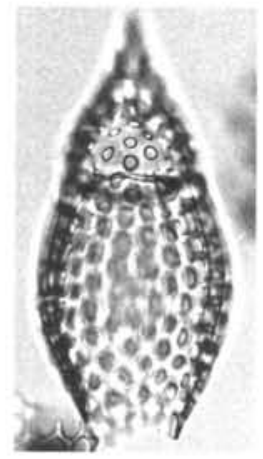

6

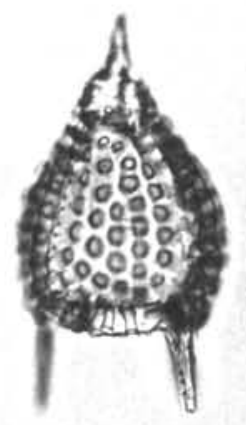

11

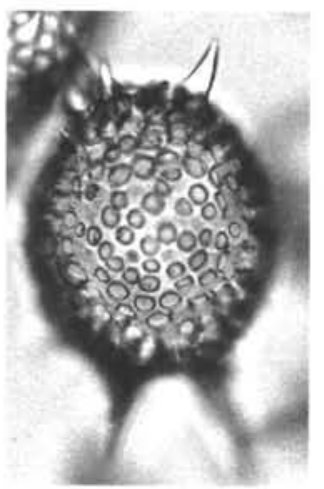

16

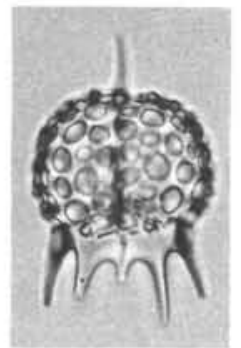

2

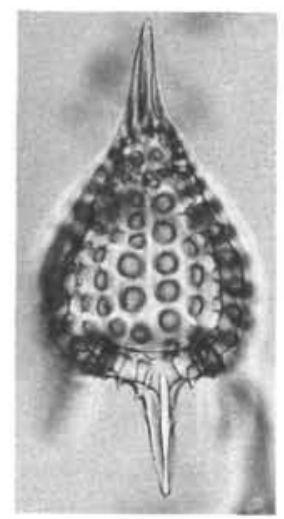

7

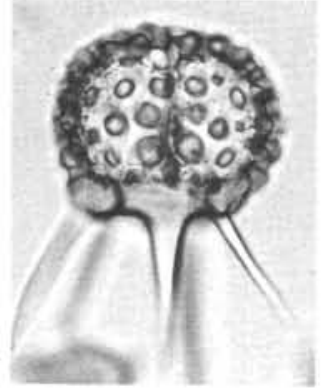

12

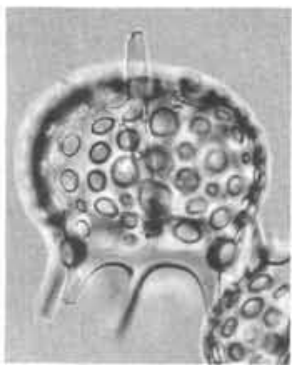

3

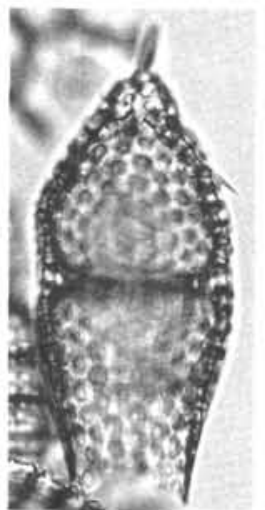

8

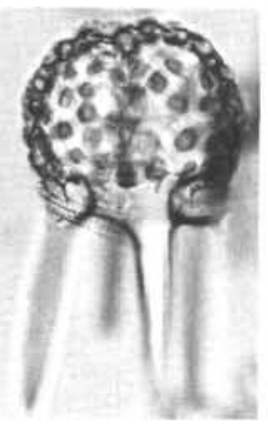

13

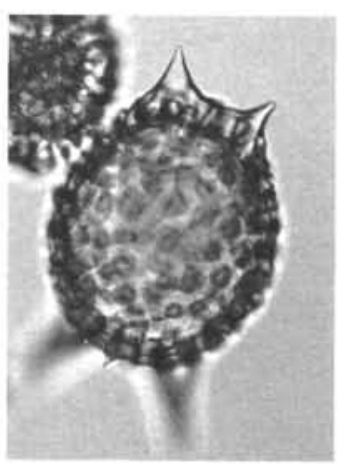

17

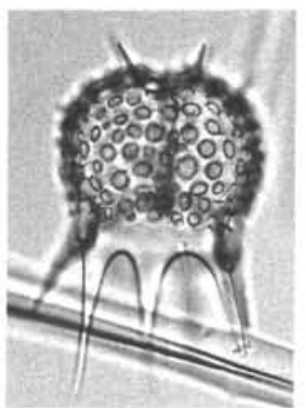

4

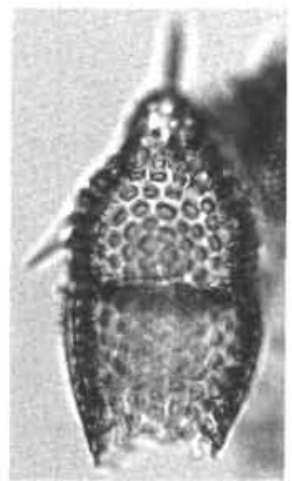

9
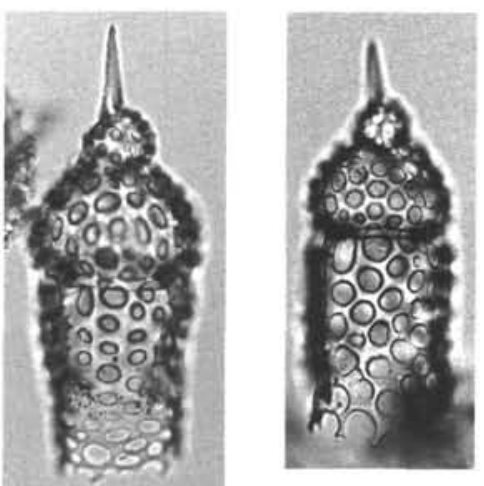

15

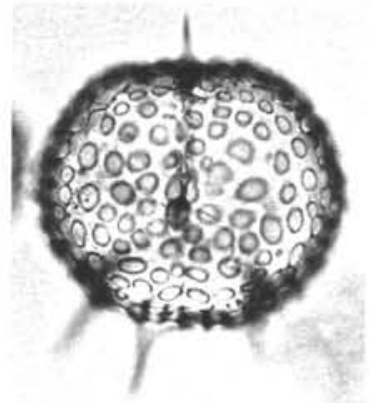

19

Plate 2. Scale bar $=80 \mu \mathrm{m}$. 1. ?Lychnocanoma sp. F; Sample 122-761B-17X-4, 67-69 cm. 2-4. Dorcadospyris sp. cf. D. platyacantha; (2, 4) Sample 122-761B-17X-4, 67-69 cm, (3) Section 122-761B-16X-CC. 5. Amphipternis sp. cf. ?Stichomitra alamedaensis; Sample 122-761B-17X-2, 67-69 cm. 6. Phormocyrtis striata striata; Section 122-761B-16X-CC. 7, 11. Lychnocanoma sp. B; Section 122-761B-16X-CC. 8, 9. Theocorys phyzella; (8) Sample 122-761B-17X-5, 67-69 cm, (9) Sample 122-761B-17X-1, 133-136 cm. 10. Amphymenium splendiarmatum; Sample 122-761B-17X-2, 67-69 cm. 12, 13. Ceratospyris sp. aff. C. articulata; Sample 122-761B-17X-1, 133-136 cm. 14, 15. Pterocodon (?) ampla; (14) Sample 122-761B-18X-2, 67-69 cm, (15) Section 122-761B-17X-CC. 16, 17. Lithomespilus mendosa; (16) Sample 122-761B-17X-1, 133-136 cm, (17) Sample 122-761B-18X-2, 67-69 cm. 18. Clathrocycloma sp. A; Sample 122-761B-17X-3, 67-69 cm. 19. Dorcadospyris sp. B; Section 122-761B-16X-CC. 


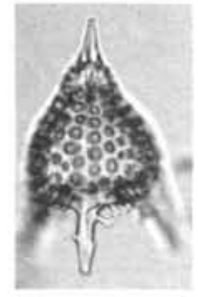

1

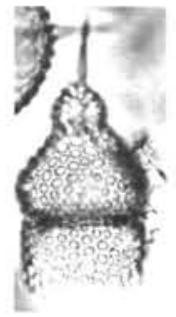

2

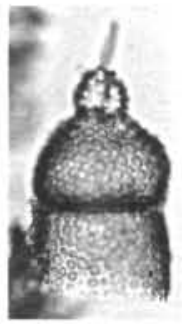

3

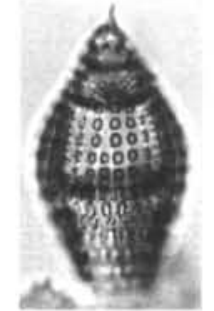

4

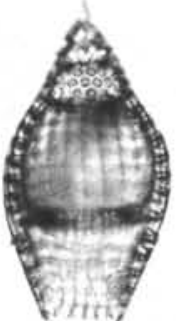

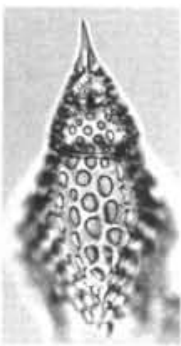

6

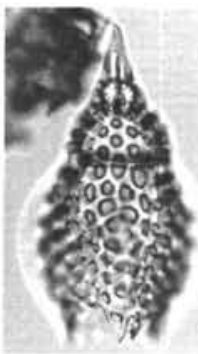

7

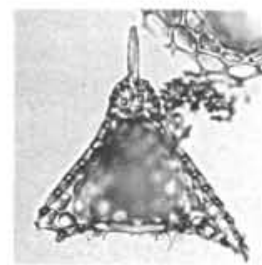

8

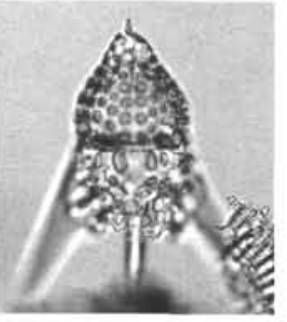

14

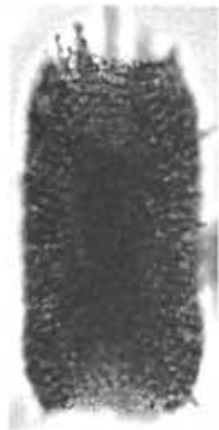

19

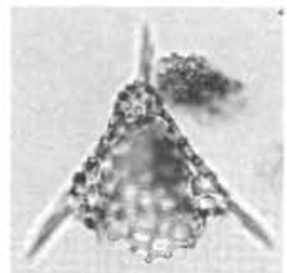

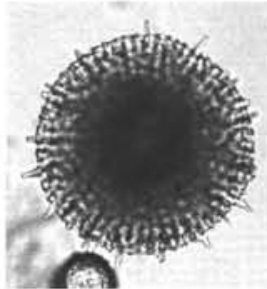

10

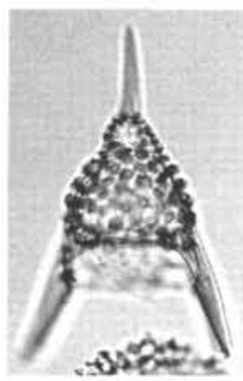

11

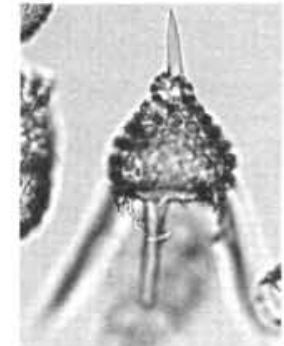

16

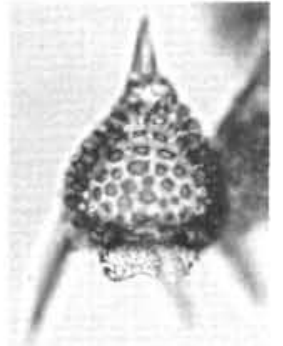

17

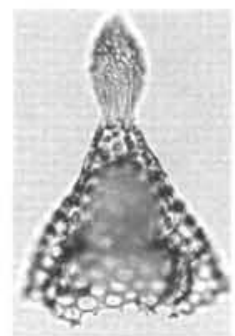

12

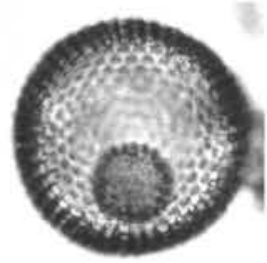

18

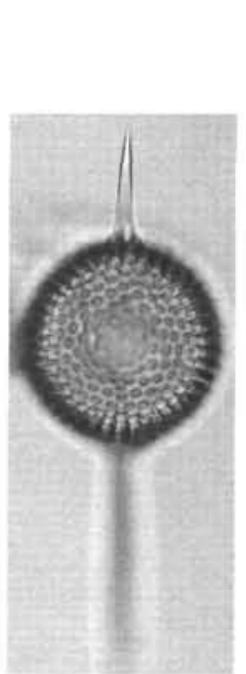

23

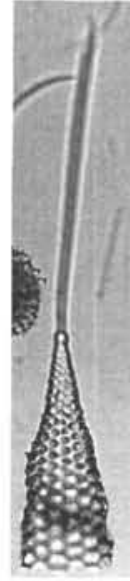

13

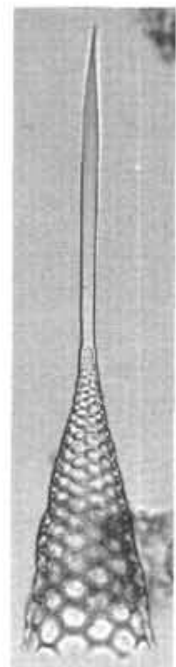

24

Plate 3. Scale bar $=60 \mu \mathrm{m} .1$, 17. Lychnocanoma sp. A; Sample 122-761B-17X-2, 67-69 cm. 2, 3. Theocorys sp. cf. T. phyzella; (2) Sample 122-761B-18X-4, 67-69 cm, (3) Sample 122-761B-17X-2, 67-69 cm. 4, 5. Buryella pentadica; (4) Sample 122-761B-17X-3, 133-136 cm, (5) Section 122-761B-17X-CC. 6, 7. Phormocyrtis striata exquisita; (6) Sample 122-761B-17X-3, 67-69 cm, (7) Sample 122-761B-17X-2, 67-69 cm. 8, 9. ?Lithochytris sp. A; Sample 122-761B-17X-6, 67-69 cm. 10. Stylotrochus nitidus; Sample 122-761B-17X-1, 67-69 cm. 11, 16. Lychnocanoma sp. C; Sample 122-761B-17X-4, 67-69 cm. 12. Dictyoceras caia; Sample 122-761B-17X-3, 67-69 cm. 13, 24. Cornutella californica; (13) Sample 122-761B-17X-2, 133-136 cm, (24) Sample 122-761B-18X-6, 67-69 cm. 14, 21. Lychnocanoma sp. D; (14) Sample 122-761B-18X-1, 74-79 cm, (21) Sample 122-761B-17X-2, 67-69 cm. 15. Lychnocanoma sp. E; Section 122-761B-17X-CC. 18. Thecosphaerella ptomatus; Section 122-761B18X-CC. 19. Spongurus (Spongurantha) quadratus; Section 122-761B-18X-CC. 20. Entapium regulare; Sample 122-761B-17X-1, $133-136 \mathrm{~cm} .22$. Entapium sp. A; Sample 122-761B-18X-3, 67-69 cm. 23. Amphisphaera minor; Sample 122-761B-17X-3, 67-69 cm. 

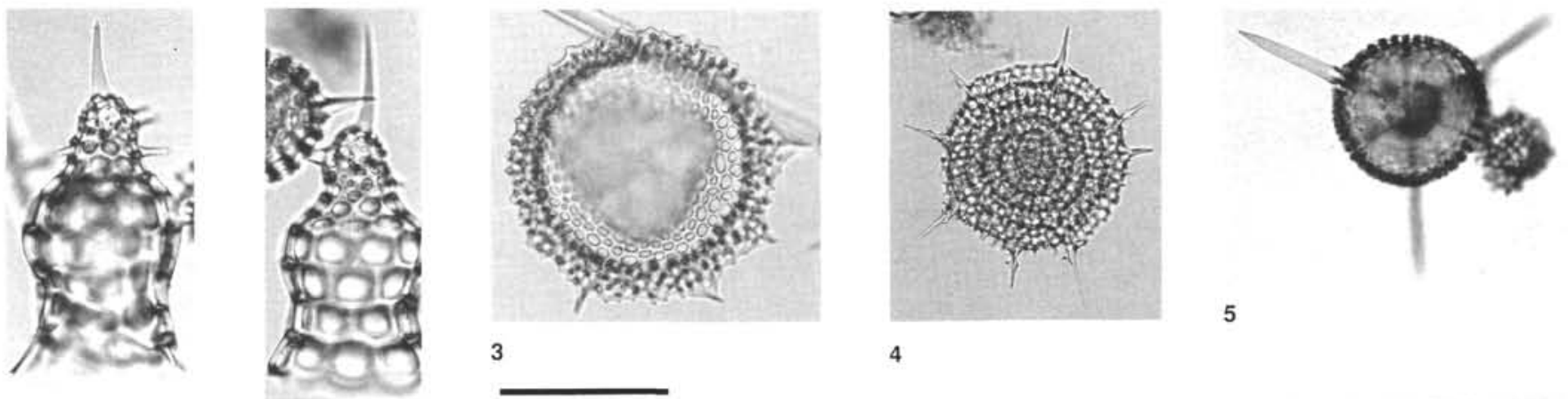

3

1

2
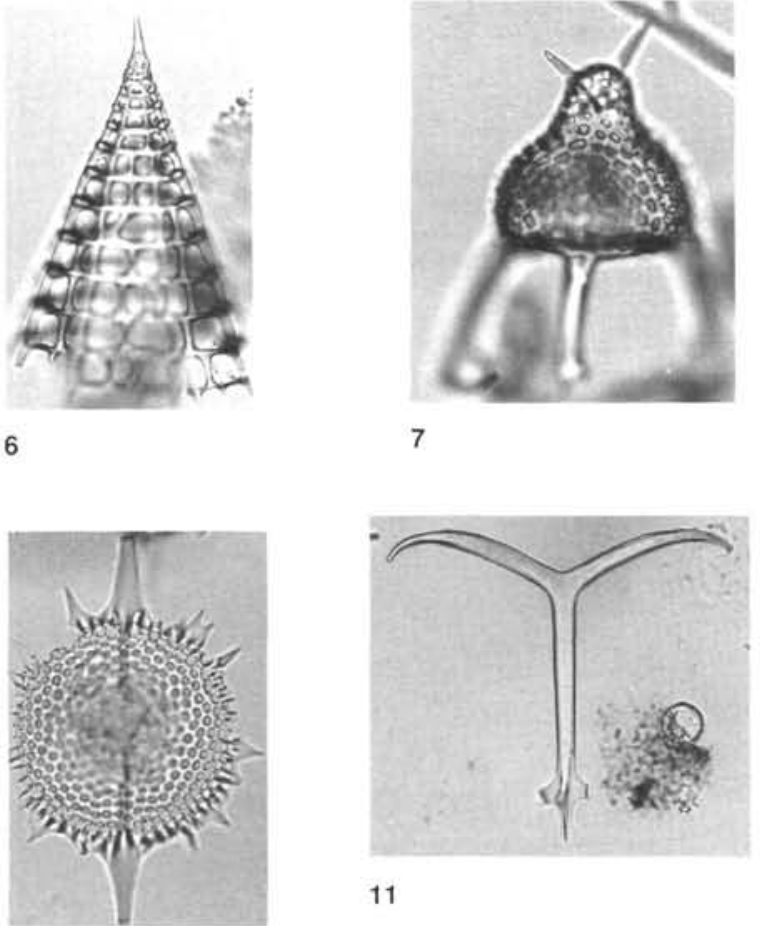

11
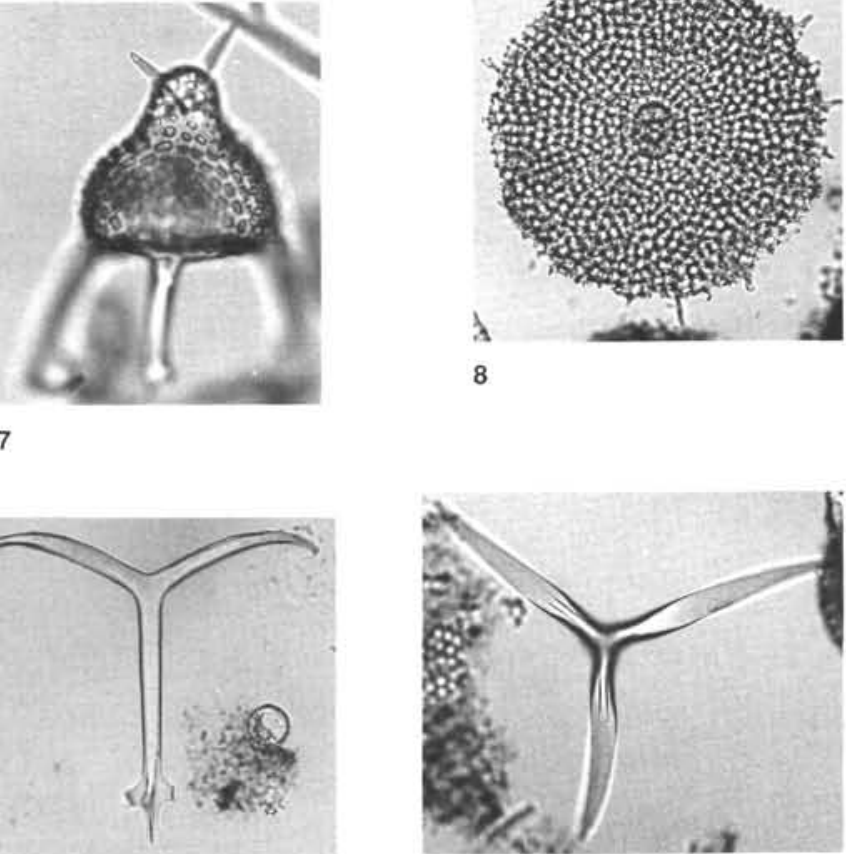

12

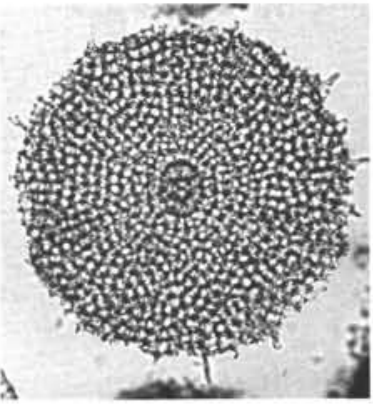

8

4

5

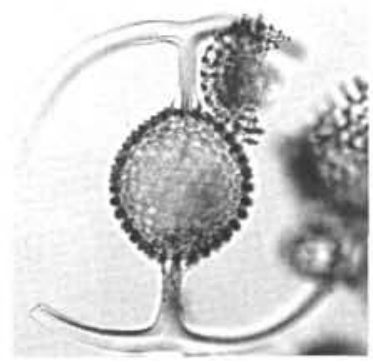

9

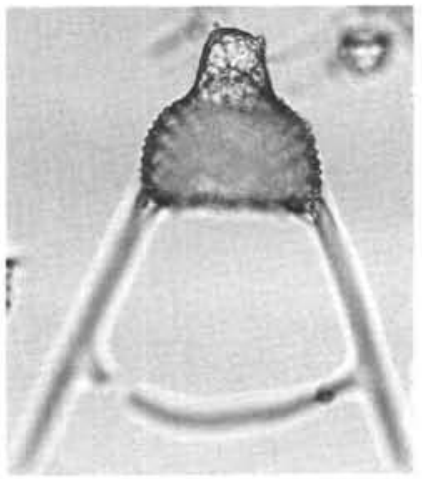

13

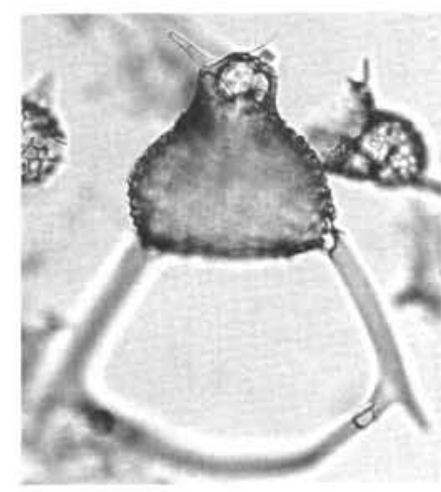

17

14

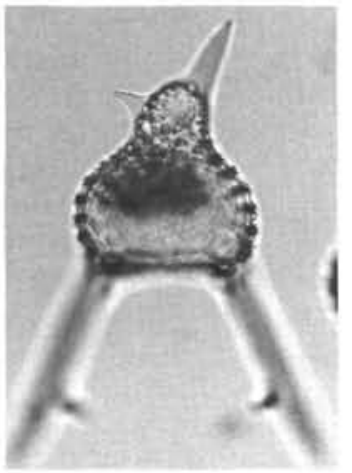

15

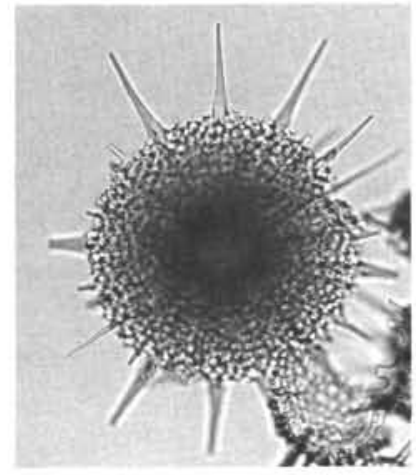

16

Plate 4. Scale bar $=60 \mu \mathrm{m} .1$, 2. Clathrocycloma parcum; Sample 122-761B-17X-2, 67-69 cm. 3. Velicucullus sp.; Sample 122-761B-18X-4, 67-69 cm. 4. Xiphospira circularis; Sample 122-761B-18X-5, 67-69 cm. 5. Entapium chaenapium; Section 122-761B-17X-CC. 6. Bathropyramis (Acropyramis) sp. cf. B. woodringi; Sample 122-761B-17X-2, 133-136 cm. 7. Bekoma sp. aff. B. campechensis; Sample 122-761B-17X-1, 133-136 cm. 8. Stylotrochus alveatus; Section 122-761B-17X-CC. 9. Saturnulus sp. A; Sample 122-761B-18X-5, 67-69 cm. 10. Heliostylus sp.; Sample 122-761B-18X-5, 67-69 cm. 11. Astrosphaerin sp. E; Section 122-761B-17X-CC. 12. Astrosphaerin sp. F; Sample 122-761B-17X-6, 133-136 cm. 13. Bekoma divaricata; Sample 122-761B-17X-1, 67-69 cm. 14. Periphaena decora; Sample 122-761B-17X-2, 67-69 cm. 15, 17. Bekoma campechensis; (15) Sample 122-761B-19X-1, 74-79 cm, (17) Sample 122-761B-17X-1, 133-136 cm. 16. Spongodiscus sp. A; Sample 122-761B-18X-4, 67-69 cm. 


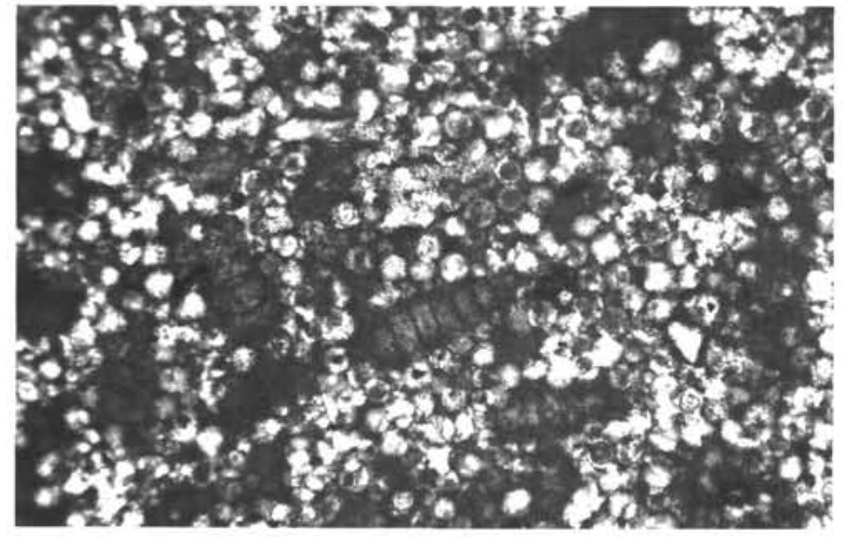

1

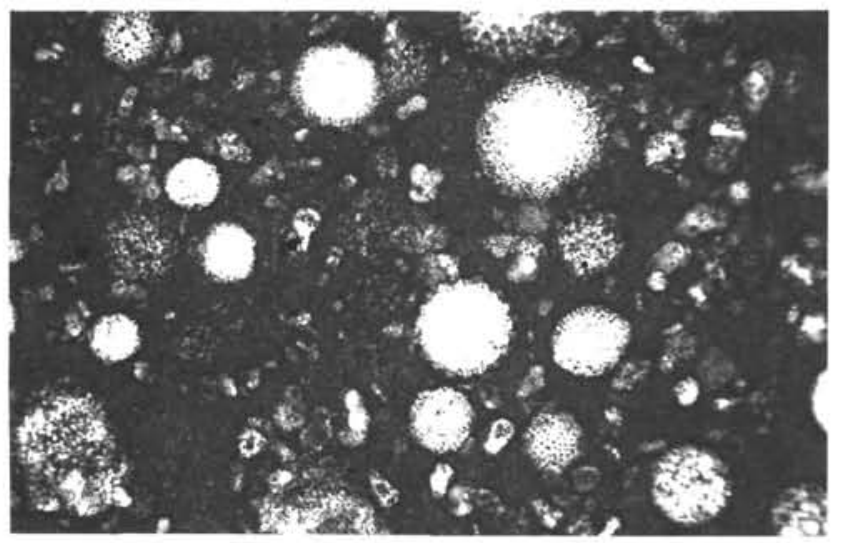

3

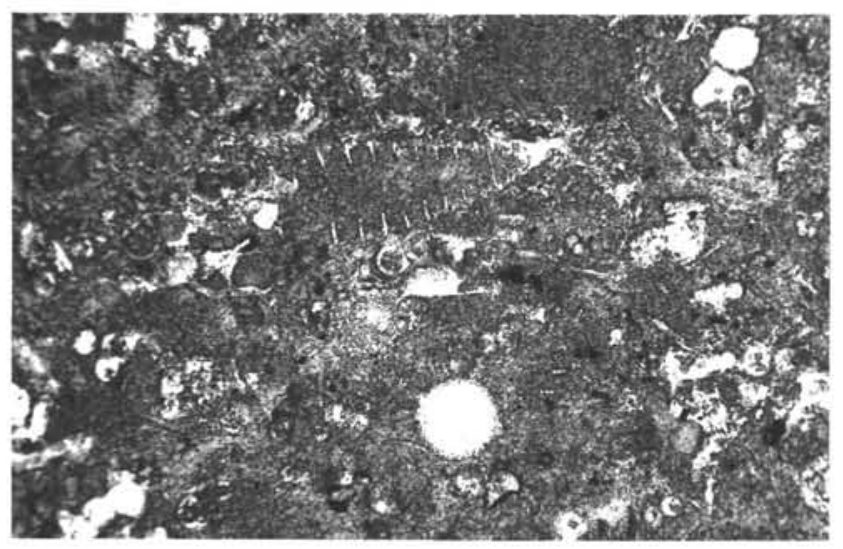

5

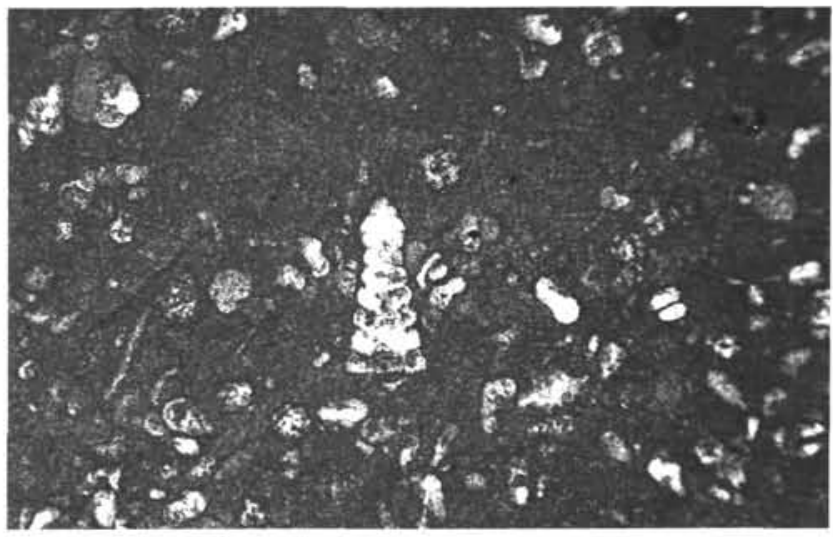

2

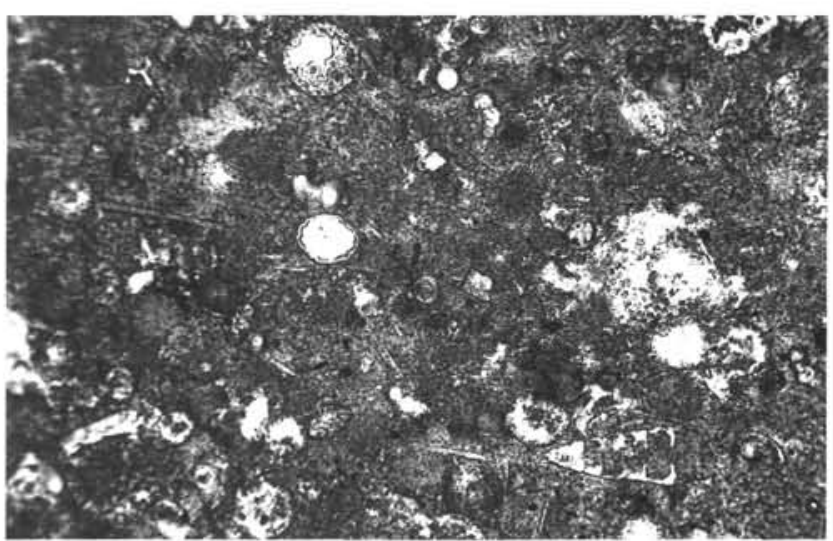

4

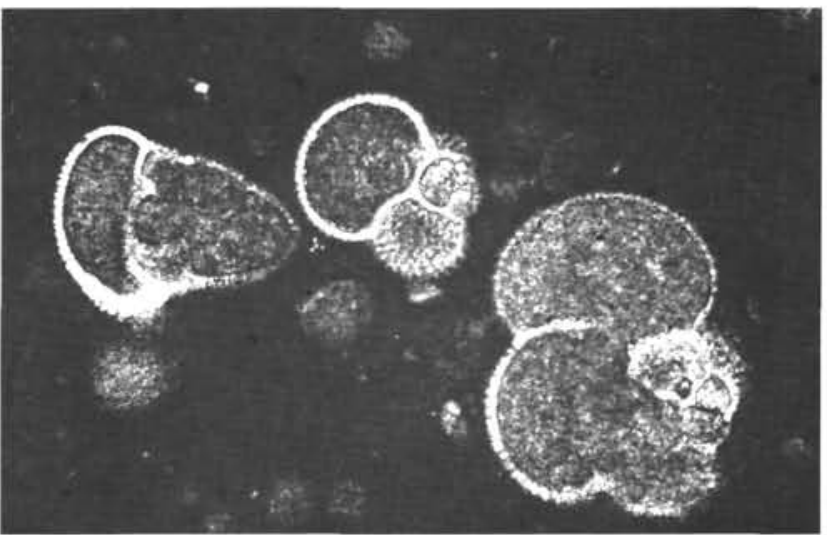

6

Plate 5. Scale bar $=800 \mu \mathrm{m}$. Transmitted-light photomicrographs of chert thin sections, all in plain light. 1. Sample 122-761B-28X-CC, 14-16 cm. 2, 3. Sample 122-761C-5R-2, 147-149 cm; note the age-diagnostic (Cenomanian-early Turonian) form, Pseudodictyomitra pseudomacrocephala, in Fig. 2. 4, 5. Sample 122-761C-6R-1, 31-33 cm; note calcium carbonate replacement of the radiolarian tests in Fig. 4. 6. Sample 122-762C-8X-3, $65-67 \mathrm{~cm}$. 